Florida International University FIU Digital Commons

$12-5-1985$

\title{
Kinetic rate constants for the formation of trihalomethanes in chlorinated ammonia containing ground water
}

Lee S. Casey

Florida International University

DOI: $10.25148 /$ etd.FI14052598

Follow this and additional works at: https:// digitalcommons.fiu.edu/etd

Part of the Environmental Engineering Commons

\section{Recommended Citation}

Casey, Lee S., "Kinetic rate constants for the formation of trihalomethanes in chlorinated ammonia containing ground water" (1985). FIU Electronic Theses and Dissertations. 2026.

https://digitalcommons.fiu.edu/etd/2026 


\section{ABSTRACT}

Kinetic Rate Constants for the Formation of Trihalomethanes in Chlorinated, Ammonia containing

Ground Water

by

Lee S. Casey

It is well established that trihalomethanes, in drinking water are byproducts of chlorine disinfection. A method to predict the distribution and concentration of trihalomethanes is important because of health risks associated with chronic exposure to these compounds. A literature review has provided information on the chemistry of water chlorination and a data base developed in the laboratory has provided data on trihalomethane formation under various conditions. These data were used to generate rate constants for the formation of trihalomethanes.

Trihalomethane formation kinetics appeared to be influenced primarily by the presence of ammonia. The influence of $\mathrm{pH}$ is not as profound as indicated in literature. The rate of formation is low at and before breakpoint, whereas it increases after breakpoint. 
KINETIC RATE CONSTANTS FOR THE FORMATION OF

TRIHALOMETHANES IN CHLORINATED AMMONIA CONTAINING

GROUND WATERS

by

Lee S. Casey

A thesis submitted in partial fulfillment of the requirements for the degree of

MASTER OF SCIENCE

in

ENVIRONMENTAL AND URBAN SYSTEMS

at

FLORIDA INTERNATIONAL UNIVERSITY

Committee in Charge:

Mr. William J. Cooper

Chairman

Associate Research Professor

Dr. J. Martin E. Quirke

Associate Professor

Dr. Gary L. Amy

Associate Professor

December 1986 
To Professors William J. Cooper, J. Martin E. Quirke, Gary L. Amy

This thesis having been approved in respect to form and mechanical execution, is referred to you for judgement upon its substantial merit.

Dean

College of Engineering and Applied Sciences

This Thesis of Lee S. Casey is Approved

Associate Professor

Associate Professor

Major: Associate Research Professor

Date of Examination: December 5, 1985 
KINETIC RATE CONSTANTS FOR THE FORMATION OF

TRIHALOMETHANES IN CHLORINATED AMMONIA CONTAINING GROUND WATER

by

Lee S. Casey

A thesis submitted in partial fulfillment of the reguirement for the degree of

\author{
MASTER OF SCIENCE \\ in \\ ENVIRONMENTAL AND URBAN SYSTEMS \\ $a t$
}

FLORIDA INTERNATIONAL UNIVERSITY 
I am grateful to my committee members and my committee chairman. I wish to thank Mr. William J. Cooper, Associate Professor and Acting Director of the Drinking water Research Center for the opportunity to assist in his research project. His patient guidance and generous support have helped immeasurably during the course of this research. Second, I should like to thank Dr. J. Martin E. Quirke for his insightful remarks concerning mechanisms, his assistance and prompting to keep this research moving towards its fruition. Third, I should like to thank Dr. Gary L. Amy, Associate Professor, University of Arizona, for taking time during his research sabbatical to serve on my committee.

Additionally, I would like to acknowledge the assistance of Dr. Louis T. Gidel, RSMAS, University of Miami, in suggesting modeling approaches to the THM reaction pathway. Lastly, I with to thank Mr. Jose L. Lopez who assistance in computer aided drafting was greatly appreciated.

This research was supported by US Environmental Protection Agency and the Drinking Water Research Center of Florida International University. 
TABLE OF CONTENTS

List of Tables . . . . . . . . . . . . . . iv List of figures . . . . . . . . . . . . . . v v Introduction . . . . . . . . . . . . . . . . 1 Review of Literature . . . . . . . . . . . . 3 Materials and Methods . . . . . . . . . . 15 Objective . . . . . . . . . . . . . . . . . 19 Results and Discussion . . . . . . . . . . 20 Conclusion . . . . . . . . . . . . . . 39 Recommendations for Future Research . . . . . . 40 Appendix I. . . . . . . . . . . . . . 41 Appendix II . . . . . . . . . . . . . 4 42 References . . . . . . . . . . . . . . 51 
TABLE 1. CHEMICAL PARAMETERS VARIED IN THE

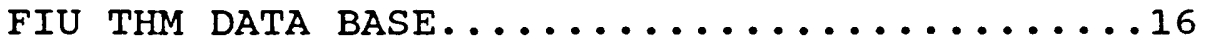

TABLE 2. STANDARD METHODS EMPLOYED IN ANALYZING

CHEMICAL PARAMETERS IN THE FIU THM

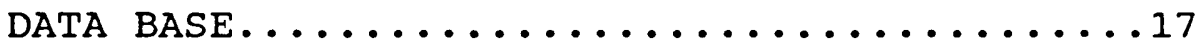

TABLE 3. SUMMARY OF AVERAGE RATES OF FORMATION

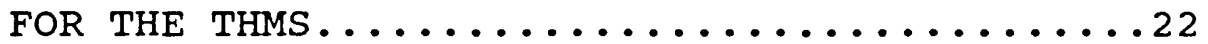




\section{List of Figures}

Figure 1. The four common trihalomethanes . . . . 4

Figure 2. Trihalomethane formation rate.... . 21

Figure 3. The breakpoint curve . . . . . . . 23

Figure 4. The haloform reaction pathway . . . . 25

Figure 5. Frequency distribution of $\mathrm{CHCl}_{3}$ rates of formation at $\mathrm{pH} 7$. . . . 28

Figure 6. Frequency distribution of $\mathrm{CHCl}_{3}$ rates of formation at $\mathrm{pH} 9$. . . . . 29

Figure 7. Frequency distribution of $\mathrm{CHBrCl}_{2}$ rates of formation at $\mathrm{pH} 7$. . . . 30

Figure 8. Frequency distribution of $\mathrm{CHBrCl}_{2}$ rates of formation at $\mathrm{pH} 9$. . . . . 31 
Figure 9. Frequency distribution of $\mathrm{CHBr}_{2} \mathrm{Cl}$ rates of formation at $\mathrm{pH} 7$. . . . . 32

Figure 10. Frequency distribution of $\mathrm{CHBr}_{2} \mathrm{Cl}$ rates of formation at $\mathrm{pH} 9$..... 33

Figure 11. Frequency distribution of $\mathrm{CHBr}_{3}$ rates of formation at $\mathrm{pH} 7$.... . 34

Figure 12. Frequency distribution of $\mathrm{CHBr}_{3}$ rates of formation at $\mathrm{pH} 9$. . . . 35

Figure 13. Pathway leading to formation of carbenes and cyclopropane . . . . . 
INTRODUCTION

A safe, disease free, potable water supply is both the desire of the public and the intent of the governmental regulatory agencies. It was with this mandate that chlorine disinfection of potable water became widespread. Recently, the safety of this disinfection technique has been questioned because trihalomethanes (THMS), suspected carcinogens, are formed during the process. Other halogenated organics are formed which may also have adverse health effects. However, THMs are readily analyzed for and are therefore used as indicators of water quality.

To minimize and understand the risks associated with THMs, comprehensive research has been conqucted to elucidate the mechanisms of THM formation, their epidemiological significance, and strategies for their control. Though certain areas have received a great deal of attention, little research to model the formation of these compounds has been conducted. Modeling efforts have lagged, in part, due to the lack of a systematically derived data base. This data base is necessary to simulate the diverse conditions encountered in raw waters. Most efforts, to date are limited to statistical summaries yielding empirical equations that are site specific and tend to overestimate the concentration of THMs formed. Kinetic models have been either too simplistic to adopt on 
2

a universal scale or are designed to simulate only the active oxidants left in a treated water. In a recent review of THM modeling, an integrated kinetic-predictive approach was recommended. The authors concluded that "...the kinetic approach will probably lead to the best predictive models." However, for the model to be of practical use, it must employ rate functions applicable to natural water systems (Cooper et al., 1983).

This thesis discusses the theoretical bases and the development of kinetic rate constants for the formation of THIs . 


\section{REVIEW OF LITERATURE}

Renewed interest in the safety of drinking water occurred after the discovery by Rook (1974) that trihalomethane formation is a consequence of water chlorination. Though the formation of contaminants is of current interest, indications of similar organic contaminants being formed in drinking water after chlorination were reported as early as the mid-1950s by Middleton and Rosen (1956). Voluminous research has been conducted on the health effects, mechanisms of formation, variation, distribution and treatment of these compounds.

Trihalomethanes (THMS) are methane compounds containing one hydrogen atom and three halogen atoms (iodine, bromine, and/or chlorine). Of all the possible compounds, generally, only four are common in chlorinated water (Figure 1). They are the trihalomethanes that contain bromine and/or chlorine (Symons et al., 1981a and 1981b). Compounds containing iodine are rarely observed. However, there is evidence for the formation and presence of the iodinated THMs in supplies whose raw waters are drawn from industrially contaminated surface waters (Bunn, et al., 1975). Trihalomethanes containing the remaining halogens, fluorine and astatine are insignificant and are never formed in the treatment process (ANON, 1980). Trihalomethanes are occasionally found in raw waters 
THE FOUR COMMON TFIHALOMETHANES

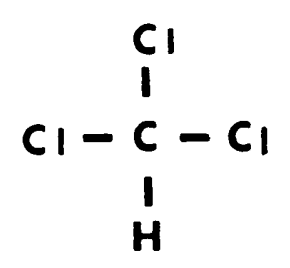

CHLOROFORM

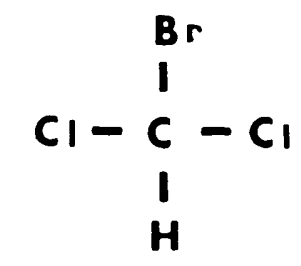

BROMODICHLOROMETHANE

DIBROMOCHLOROMETHANE

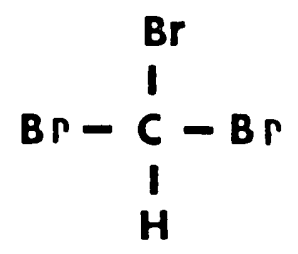

BROMOFORM

Figure 1. The structure of the Common Trihaldmethanes. 
(Dreisch, et al., 1980), but in general, are not found in significant concentrations. They are likely to be found in chlorinated waters that contain naturally occurring organics, i.e. humics and fulvics. This is especially true in Florida where many water supplies contain significant proportions of these organics (Dykes, 1980).

Variations in THM concentrations occur on diel, day-to-day and seasonal bases. Diel variations are both significant and complex as are the day-to-day variations. The variations are thought to be controlled by several physical/chemical factors. However, the relationships among these factors is unclear (Smith, et al., 1980). The seasonal variations are less complex. Lower total trihalomethane (TTHM) levels occur during the winter months (Arguello, et al., 1979). These depressed levels are attributed to lower precursor level (i.e. lower algal production) and lower temperatures.

Research into the health effects of chlorinated drinking water is continuing. This research involes, not only the effects ot THMs, but also chloramines and heavier refractory chlorinated organics. Water chlorination and, therefore, the THMs have been linked via epidemiological research to significantly higher incidents of gastrointestinal tract cancers (McCabe, 1977). There is also evidence suggesting that the alternative disinfectant chloramines are potentially mutagenic and are associated with methemoglobinemia (Bull, 1982). One recent study 
(Kringstad, et al., 1983) has reported on the formation of the mutagens, 1,3-dichloroacetone and 2-chlorophenol, with chloroform when humic acids are chlorinated.

Though it now appears from the recent literature that the THMs may not solely be responsible for health risks associated with chlorinated waters, they are potential carcinogens and may be indicative of other carcinogenic compounds, which are not easily analyzed. In response to this perceived health risk, the USEPA has regulated TTHM to a maximum allowable concentrations of $100 \mathrm{ug} / \mathrm{L}$. This regulation applies to treatment operations serving more than 10,000 people (Federal Register, 1979).

Presently, there are two approved methods for the analysis of THMs by gas chromatography, purge and trap and liquid-liquid extraction. The former was the first method to be developed (Bellar and Lichtenberg, 1979; Kissinger and Fritz, 1976). The purge and trap method has been shown to suffer from interference by ammonia when Tenax GC was used for separation. The method was modified by employing a mini-ion exhange column to remove ammonia prior to purging (Cooper et al., 1984). Another drawback of the purge and trap method is the amount of time required for a single analysis.

The liquid-liquid extraction method was developed shortly after the purge and trap. This method has a number of advantages over the purge and trap, specifically, higher sensitivity, better precision and a significantly decreased 
time of analysis (e.g. Mehran, et al., 1984; Reding et al., $1979)$.

By far, the largest section of the literature is devoted to strategies and technigues for the control of THMs. Strategies refer to those modifications of a treatment system whose aim is to minimize or, ideally, eliminate the formation of the THMs, while techniques are those processes or modifications designed to remove THMs after their formation (Blanck, 1979).

These strategies and techniques include precursor removal and THM removal by a variety of physical and chemical methods and the use of disinfectants other than chlorine. Excellent overviews have been recently published by sober et al., (1982) and Knoppert, et al., (1980).

The alternative disinfectants include: ozone, chlorine dioxide and chloramine (ANON. 1982; Hoff and Geldreich, 1981). Ozone is the best biocide, however its stability is poor; no residual remains in the distribution system and it is the most costly of the disinfectants. Despite its high cost it is reported as having a favorable cost benefit ratio (clark, 1981). Though there is some disagreement, ozone appears to be able to destroy precursors and when coupled with ultraviolet light, is reported to destroy refractory organic compounds (Hubbs, 1981; Glaze et al., 1978).

Chlorine dioxide is a good biocide with reasonable 
stability (Hubbs et al., 1981). Though this latter point is suspect (zika et al., 1982). It has the advantage of not reacting with ammonia or organo-amine compounds to form chloramines and its biocidal activity is enhanced with an increased $\mathrm{pH}$.

Monochloramine appears to be stable but the biocidal efficiency is the poorest of the alternative disinfectants. Both enteric viruses and protozoan cysts are resistant to chloramine attack. Cost savings have been reported using this disinfectant in the Miami area, however it should be noted that this particular water supply has relatively high, naturally occurring, ammonia concentration and a very high THM formation potential (Sloan, 1983; Belick et al., 1983).

Another strategy to control THMs that has received a great deal of attention is the removal or reduction of $T H M$ precursors. Activated carbon has been using singly or coupled with other processes to remove humic precursors (Glaze and Wallace, 1984). The removal potential of ozonation, ultraviolet light, coagulation (Babcock and Singer, 1979; Thurrott and Duryea, 1983), direct filtration (Scheuch and Edzwald, 1981), and permanganate oxidation/ manganese dioxide absorption have been evaluated (colquist et al., 1982). Most research focuses on the potential of activated carbon, (Wood and DeMarco, 1979; Rice, et al., 1978). Activated carbon can successfully remove precursors 
but the removal efficiencies are influenced by a number of factors. Both biological activity and pore size affect removal. Microorganisms may play a role in removing the higher molecular weight fractions (Stevens, et al. 1979).

Pore volumes of $70 \AA$ correlate well with the removal of humic and fulvic acids having molecular weights of less than 1000, while pore volumes of $400 \AA$ correlated with the removal of fulvic acids with higher molecular weight.

Another interesting development, which may be loosely considered a strategy, as defined previously, is a system for monitoring synthetic organic loads along the Ohio River (Moore, 1980). The objective of this network is to act as an early warning system for consumers downstream of a monitoring site. This, in theory, will allow operators time to adjust the treatment process to maximize contaminant removal and minimize THM formation.

Two techniques have been developed to remove THMs from finished water. They are activated carbon and aeration or air stripping. Several types of carbon filtration systems have been evaluated in both pilot scale and plant scale experiments (Wood and DeMarco, 1980; Feige and DeMarco, 1980). Generally, these absorbents are effective in reducing the THMs.

In the aeration process, air is passed through the water to purge volatile organic compounds. A preliminary cost analysis for such a system indicates that it can be a 
cost effective method of removing THMs and other organic contaminants (Kavanaugh and Trusell, 1980).

An understanding of organic precursor compounds is essential to partially clarify the temporal and spacial variations of THMs.

Precursor is the general term used to describe the organic content of raw waters that react with chlorine to form THMs. It is believed that precursors are mainly humic and fulvic acids which are the degradation products of plant material, but low molecular weight methyl ketones, meta-dihydroxy aromatic compounds, algae and their extracellular products have also been cited as precursors (Lee et al., 1982; Hoehn, et al., 1980; Oliver and Lawrence, 1979; Rook, 1977). The best definition to date of precursor substances is "...an amorphous mass of poly-hetero condensate with certain reactive functional groups protruding from the particle's surface" (Trussel, 1978; Umphres, et al., 1981).

Since chlorine dose (concentration) is the one variable that is directly under the control of the engineer or operator, research has been conducted into understanding aqueous chlorine chemistry as it relates to THM formation. Early work centered on a qualitive understanding of chlorination, halogen ions and the organic carbon content of a water (Rook, 1974; Bunn, et al., 1975). Later research was restricted to studies of chlorinated compounds 
found in chlorinated potable and waste waters (Stevens, et al., 1976); Morris and McKay, 1975; Dore, et al., 1978; Cooper, et al., 1981a). Chlorine reacts with both fulvic and humic acids (Noack and Doerr, 1978; Qualls and Johnson, 1983). It also reacts with bromide ion (Wong and Davidson, 1977) and ammonia (Saunier and Selleck, 1979). A brief framework of the reactions of chlorine in both fresh and saline waters can be developed. In the presence of ammonia, hypochlorous acid (HOCl) will react to form chloramines. The chloramines can further react in the presence of HOCl to form end products, either nitrogen gas or nitrate ion. When bromide ion is present, hypobromous acid $(H O B r)$ is formed. This reacts in a manner similar to chlorine, forming brominated amines. It is believed that the THMs are formed when organic carbon compounds react with either HOCl or HOBr via the generalized haloform reaction.

As mentioned previously, bromide ion reacts rapidly and irreversibly with HOCl to form HOBr, which can form brominated THMs in a similar way to HOCL. The brominated THMs are also suspected carcinogens and may be more harmful than chloroform. The chemistry of bromide in the presence of high levels of organics and ammonia has been recently studied (Cooper, et al., 1984; Cooper, et al., 1981a; and Luong, et al., 1982). Studies by Johnson and co-workers (1982) and Carpenter and co-workers (1978a \& 1978b) on the 
reactions of bromide-chlorine reactions in sea water are highly significant. The results give information on reactions in chlorinated drinking waters that suffer from salt water intrusion and thus contain high levels of bromide ion. The degradation reactions of the brominated amines are poorly understood with the exception of tribromamine (LaPoint, et al., 1975). This amine in aqueous solution decomposes to nitrogen gas and bromide ion. The hydrogen ion concentration can vary considerably from treatment plant to treatment plant. It is well established that yields of THMs are affected by changes in pH. This may be due in part to the catalytic effect it has on the degradation reactions of the hypohalites (Chapin, $1934)$.

The effects of near ultraviolet radiation on oxidants has been ignored until recently (zika et al., 1982). It was demonstrated that sunlight can induce the decomposition of $\mathrm{HOBr} / \mathrm{OBr}^{-}, \mathrm{HOCl}^{-} / \mathrm{OCl}^{-}$, and to a much lesser extent $\mathrm{NH}_{2} \mathrm{Cl}$. The decomposition is enhanced at basic $\mathrm{pH}$ values. Another significant aspect of photo effects is the induced formation of bromate ion in chlorinated waters containing bromide ion (Maclady, et al., 1977).

There are very few viable models of THM formation during water treatment. This is due, in part, to an incomplete understanding of the chemistry of the THMs. Recent empirical models can predict THMs fairly accurately, 
however these are specific for one water and therefore they are of limited use. Cooper et al., (1983) have reviewed current modeling efforts.

Models can be divided into three types. The first, and simplest type, is the use of model compounds to mimic the humic precursors. This approach, which has not always been explicitly recognized as a modeling method, has been used by several authors. Acetone (Dore, et al., 1978),

$\alpha$-methyl-benzyl-amine (Cooper and Kaganowicz, 1985) and selected aromatic compounds (Norwood, et al., 1980) have been used as models of precursors. The chlorination products of these compounds have been examined.

The second type is the empirical model. This model uses statistically derived values for the major variables and relates them in a linear fashion to the amount of THMs formed (Engerholm and Amy, 1981; Morrow and Minear, 1983; Amy, et a1., 1983; Fisher and Taylor, 1983; Urano et al., 1983).

The last type is a kinetic model. This type holds the greatest potential for both accurate prediction and broad applicability. A kinetic model of THMs is based on reaction rates and concentrations of chemical species known or theorized to occur in chlorinated waters. Though kinetic models have not been used to predict THMs per se, they have been widely employed to predict active halogen species in chlorinated power plant effluent (Kavanaugh, et 
al., 1980; Margerum et al., 1978; Gray et al., 1978;

Johnson et al., 1982; Sanguinsin and Morris, 1979; Uden and Miller, 1983; Wei and Morris, 1974; Zielke, et al., 1978; Lietzke, 1977a; Nelson, 1978; Haag and Lietzke, 1981; Johnson and Qualls, 1983; Lietzke, 1977b). Considerable additional research is necessary before the kinetic approach is applicable to the water treatment process. 
MATERIALS AND METHODS

This research is based on the THM analysis series performed over the past four years at the F.I.U. Drinking Water Research Center (Kashfian, 1984; Cooper et al., 1983). A brief outline of the analytical methodology used to develop the data base is in order even though chemical analysis were not part of this research.

This data base reflects experiments to analyze the effects of ammonia, bromide, chlorine dose, $\mathrm{pH}$, reaction time, temperature and total organic carbon (TOC) on THM yields. Each parameter was varied while the others were held constant (Table 1). The THM yield for each species was determined.

THMs were determined using a Tracor 560 gas chromatograph with Hall Model $700 \mathrm{~A}$ conductivity detectors. Two analytical methods were used, the purge and trap technique (Kashfian, 1984) and the liquid-liquid extraction (Mehran et al., 1984). Raw waters were characterized using standard methods (Kashfian, 1984; Table 2).

Previous research (Cooper, 1981a; Kashfian, 1984) has provided a comprehensive data base for $T H M$ formation under various raw water and operating conditions. This data base was used to obtain formation rate constants for the four THMs. Data were partitioned by breakpoint level i.e. before breakpoint, at breakpoint, and after breakpoint. 
16

TABLE 1. EXPERIMENTAL DATA BASE USED TO FORMULATE RATE CONSTANTS

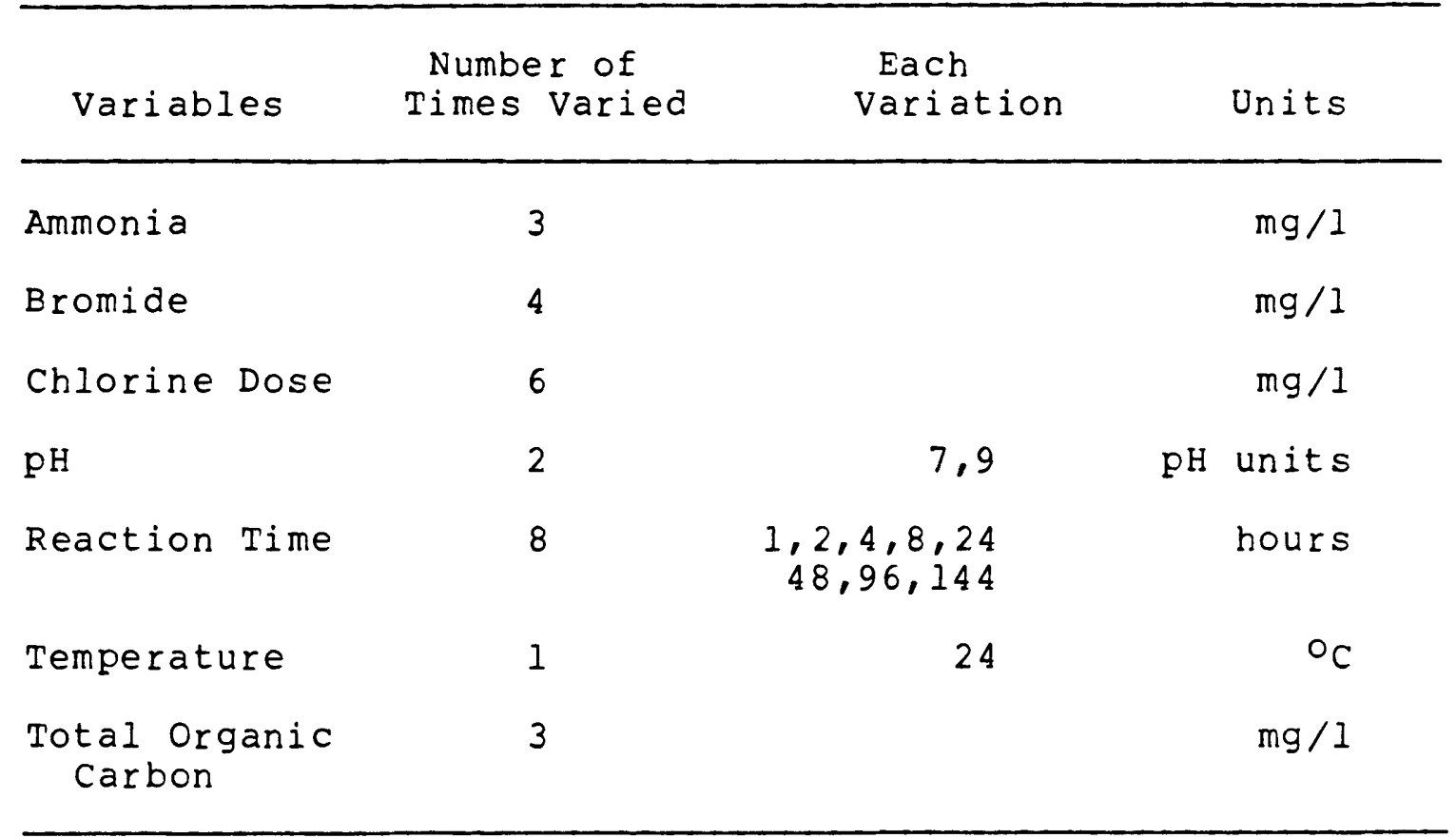


TABLE 2. CHEMICAL TESTS FOR CHARACTERIZATION OF GROUND WATER (AFTER KASHFIAN 1984).

TEST

METHOD

Alkalinity

$403, \mathrm{P} 278$ *

Hardiness

$308 \mathrm{~B}, \mathrm{P} 202^{*}$

$\mathrm{Cl}^{-}$

Dionex Ion Chromatograph

$\mathrm{SO}_{4}-2$

Dionex Ion Chromatograph

$\mathrm{NH}_{3}-\mathrm{N}$ (Nesslerization)

$418 B, P 412 *$

$\mathrm{pH}$

Glass electrode

TOC

Dohrman DC-54 TOC analyzer

*Standard Methods 14 th Edition 
18

After sorting, THM values were plotted versus time to identify the order of the reaction. A least squares regression analysis was used to evaluate the linearity of the plot. Ultimately, a log-log transformation was used to linearize the data. The slope of the regression line of each experiment was obtained. These slopes, which represent rate constants from each experiment were pooled and averaged for each breakpoint classification. Only those regressions have correlation coefficients of 0.7 or better were used. Geometric means and arithmetic means were computed as measures of central tendency of the population of rate constants. A students t-test was used to determined significant differences between derived rate constants. 
OBJECTIVE

The major objective of this research was:

To determine simple formation rate constants for each of the four common trihalomethanes. 


\section{RESULTS AND DISCUSSION}

\section{General}

Rate of formation data when plotted versus time yielded a curve characterized by a power function (Figure 2). This type of distribution has been observed before for trihalomethane reactions (Urano, et al., 1983) and is of the form:

$$
\mathrm{THM}=C t^{\mathrm{k}}
$$

$$
\text { Where: } \quad \begin{aligned}
& \quad C=\text { empirical constant } \\
& k=\text { reaction rate constant } \\
& t=\text { time in seconds }
\end{aligned}
$$

Derivation of this function appears in Appendix I. A log distribution is not unexpected when analyzing environmental data (Dean, 1981).

Table 3 is a summary of $k$ and $C$ constants based on results of linear regressions. Only data from regressions with correlation coefficients $(r)$ of 0.70 or better were used in obtaining averages of rate constants. Of the data used, $81 z$ have correlation coefficients of 0.9 or better. Table 3 summarizes rate constants for each THM species at 3 points along the breakpoint curve (Figure 3 ). "k" is the rate of formation in reciprocal mole/liter/second units while "C" is an estimate of the 


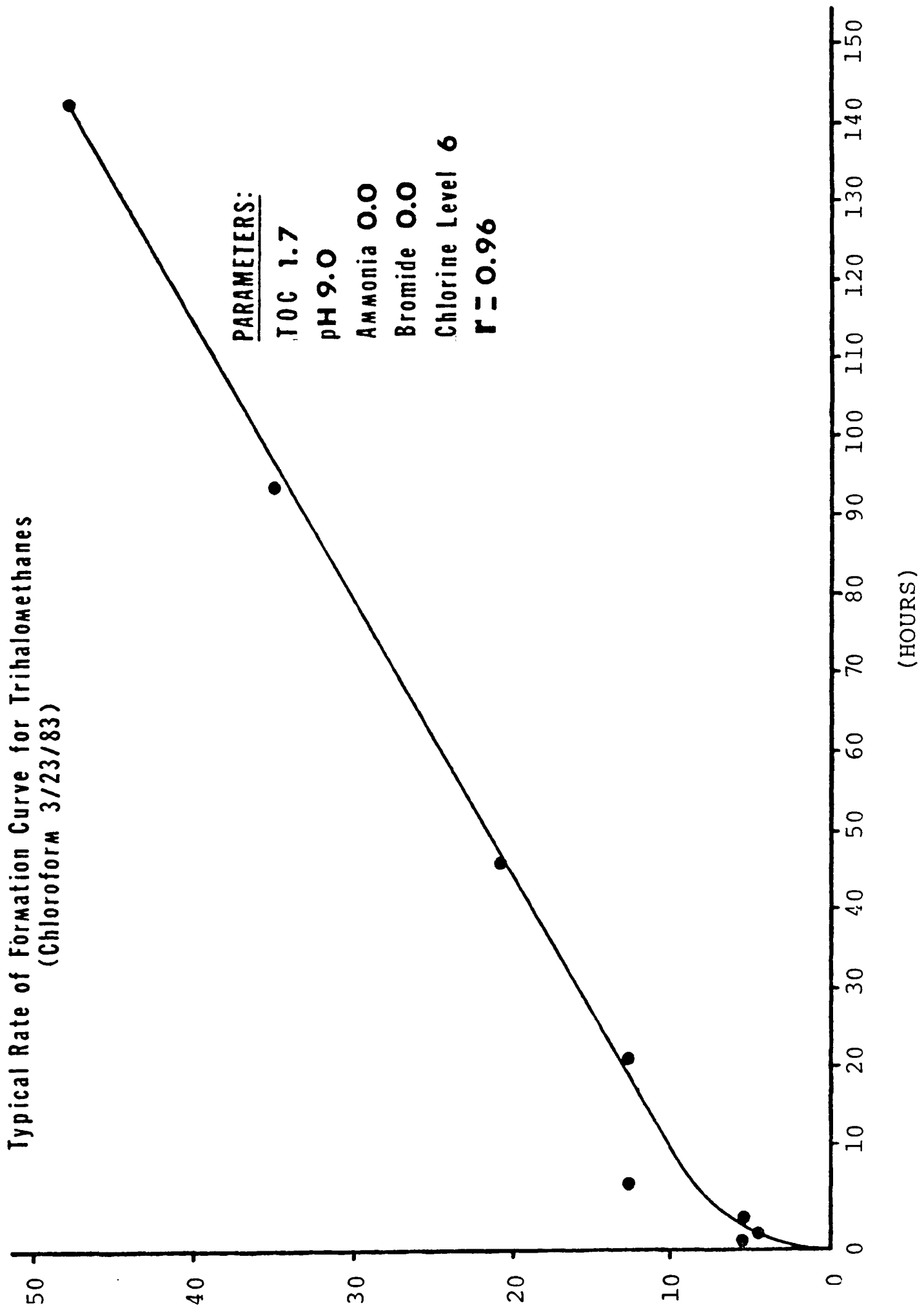

Figure 2. Trihalomethane Formation Rate Curve 


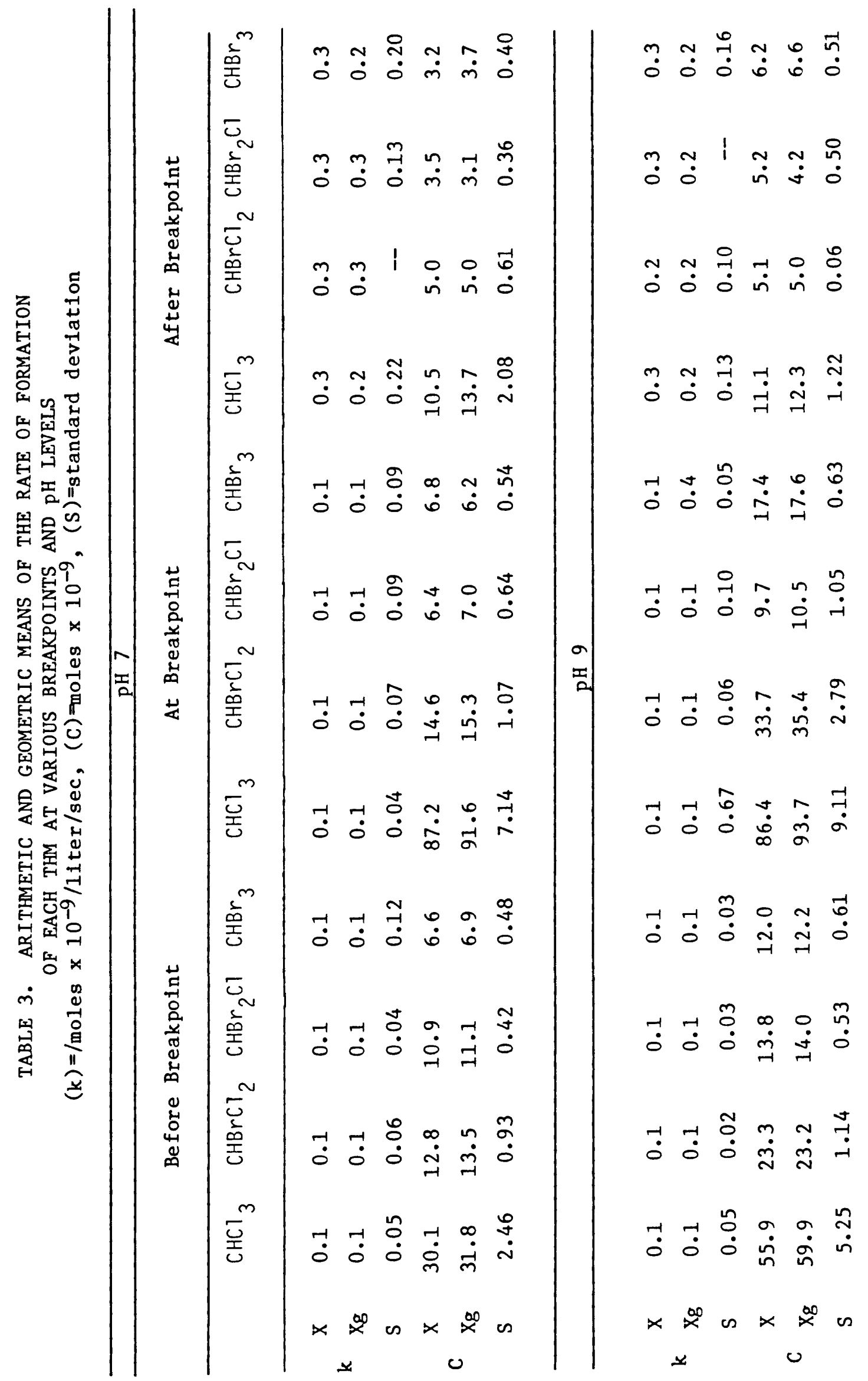




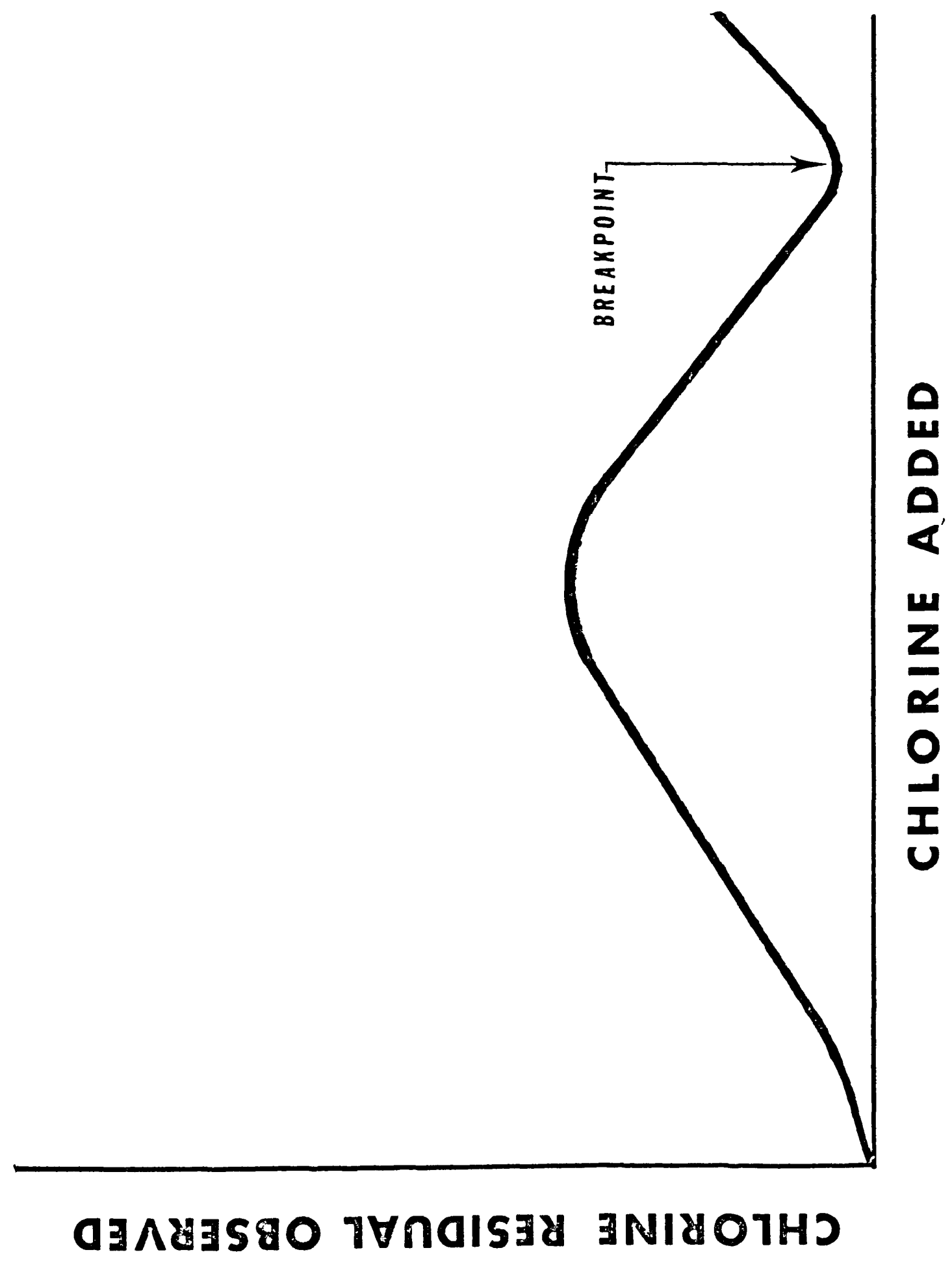

Figure 3. The Breakpoint Curve 
THMs formed after one hour. The present model is based on data for contact periods from one hour to 144 hours only. The instantantous $T H M$ reactions have been ignored in this experiment because the objective of the analytical work was to estimate the effect of actual field contact times on the yield and distribution of THMs. The instantaneous rate of formation appears to be much more rapid than the long term rate of formation (Cooper, et al., 198lb). Note that after approximately one hour a different rate of formation in chlorinated wastewater was observed. Hence, "C" is an estimate of the amount of THM species formed between 0 and 1 hours. While "k" represents a rate of formation for reactions occurring between 1 hour and 144 hours.

In general, much higher rates of formation are obtained after the breakpoint than before. This is well documented. Rates of formation before and at the breakpoint are lower at $\mathrm{pH} 9$ than at $\mathrm{pH}$ 7. This is unexpected since THM formation is based catalyzed. Note however that " $C$ " values are significantly higher $(\alpha=0.05)$ at $\mathrm{pH} 9$. This indicates that the reaction between 0 and 1 hour is much more rapid at $\mathrm{pH} 9$. the statement that the THM reaction is based catalyzed, therefore only applies to the earliest reactions; those occurring between 0 and $l$ hour. It is possible another reaction pathway other than the haloform reaction (Figure 4 ) is being followed. Perhaps there are multiple pathways 
THE HALOFORM

REACTION

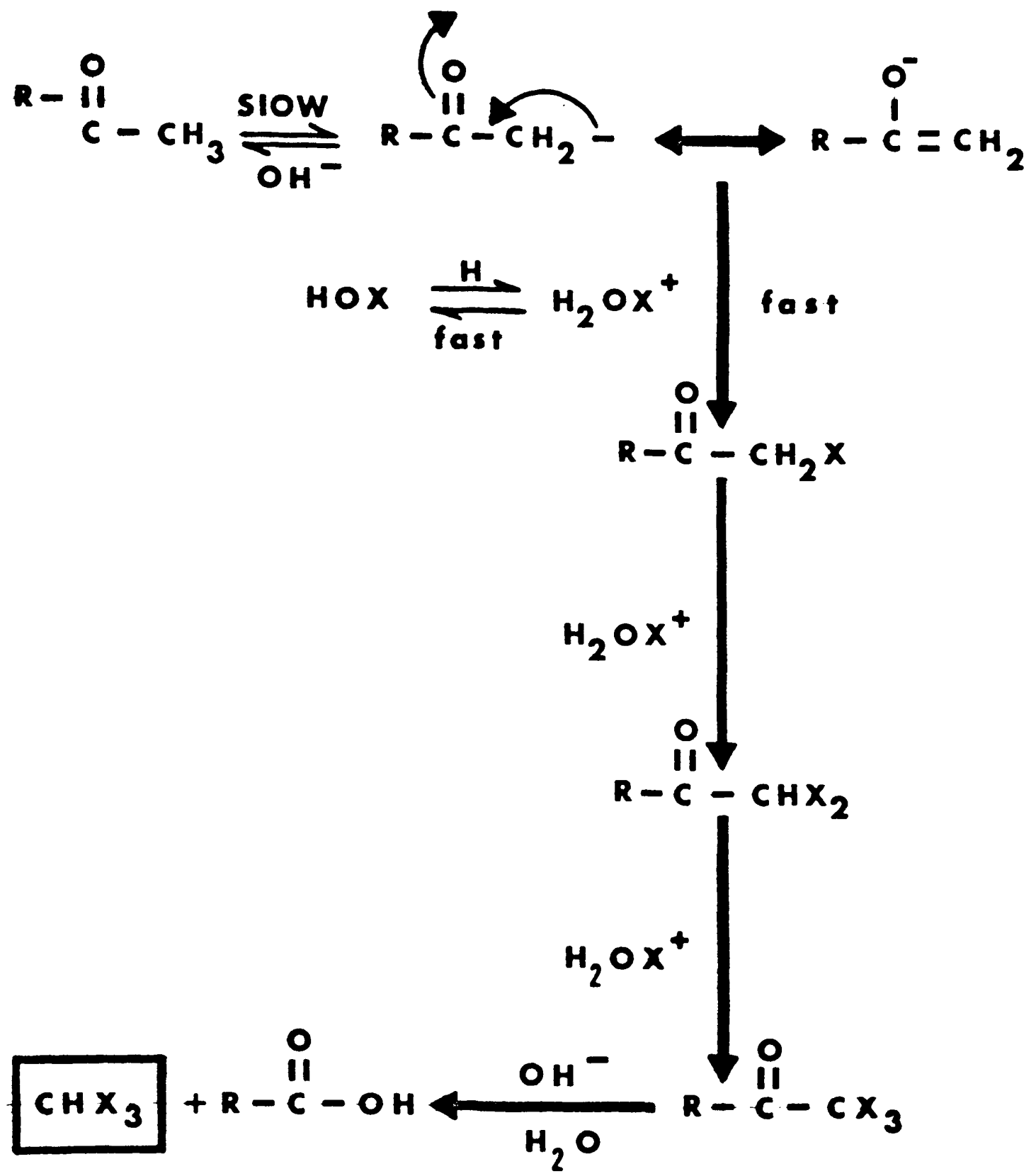

Figure 4. The Haloform Reaction Pathway 
leading to THM formation (Cooper, et al., 1983).

As mentioned previously, all data from the experiments were pooled to obtain estimates of both the $Y$ intercepts (C) and slopes ( $k$ ) of linear regressions. The rates of formation (slopes of regression lines) of all four species of THMs, however, do not differ significantly $(\alpha=$ 0.05 ) before the breakpoint at either pH (Figures 5-12). At the breakpoint the spread of the date for each THM becomes noticeable. Results of the $t$ test indicate that these rates do not differ significantly from one another. After breakpoint, data for rates of formation are spread but again there appears to be no significant difference in the rates of formation between the four species of THMs. However, it is important to discuss the difference observed in the rates of reaction of individual species as a function of the point on the breakpoint curve.

Chloroform's rate of reaction will be approximately the same either at or before the breakpoint. A trend of increasing data scatter is apparent in this instance. After the breakpoint data are highly scattered with high and low individual rate constants ranging from 0.4376 $0.0417\left(\mathrm{x} 10^{-9} / \mathrm{mole} / \mathrm{iter} / \mathrm{sec}\right)$ at $\mathrm{pH} 7$ and from 0.5007 $0.053\left(\mathrm{x} 10^{-9} / \mathrm{mole} / \mathrm{liter} / \mathrm{sec}\right)$ at $\mathrm{pH} 9$ (Figures $5 \& 6$ ). The distributions in both cases appear to have two clusters of observations approximately centered at 0.10 and $0.33 \mathrm{x}$ $10^{-9} /$ mole/liter/sec. 
Bromodichloromethane rate constants show a greater degree of scatter at the breakpoint than those of chloroform. Data before the breakpoint are tightly grouped. After breakpoint two clusters of data obvious at approximately 0.22 and $0.43\left(\right.$ x $\left.10^{-9} / \mathrm{mole} / \mathrm{liter} / \mathrm{sec}\right)$ at both $\mathrm{pH} 7$ or $\mathrm{pH} 9$ (Figures 7 and 8 ).

Dibromochloromethane rate constants are tightly clustered before breakpoint. However, at breakpoint data appear clustered in three peaks centered approximately at $0.05,0.14$ and $0.33\left(\times 10^{-9} / \mathrm{mole} / 1\right.$ iter $/ \mathrm{sec}$. This is most obvious at $\mathrm{pH}$ 9. (Figures 9 and 10). After breakpoint most rates appear to fall into two clusters.

Bromoform rates follow the general trend before breakpoint and at breakpoint. That is, tightly clustered before the breakpoint, increased scatter at the breakpoint. After breakpoint, rates are scattered with nearly uniform frequency ranging from 0.0298 to 0.793 ( $\mathrm{x}$ $10^{-9} / \mathrm{mole} / 1$ iter $/ \mathrm{sec}$ ) at $\mathrm{pH} 7$ and 0.0275 to 0.5719 (x $10^{-0} / \mathrm{mole} / \mathrm{liter} / \mathrm{sec}$ ) at $\mathrm{pH} 9$ (Figures 11 and 12 ).

In the preceding discussion it, was noted that there is an increase in scatter of the rate constants $(k)$ after the breakpoint (Figures 5 to 12). The increased scatter can be explained superficially by variation in analytical technique or variations due to the wide number of conditions under which the species were formed. Though these are possibilities, if these explanations were 


\section{CHLOROFORM PH7}

Before Breakpoint

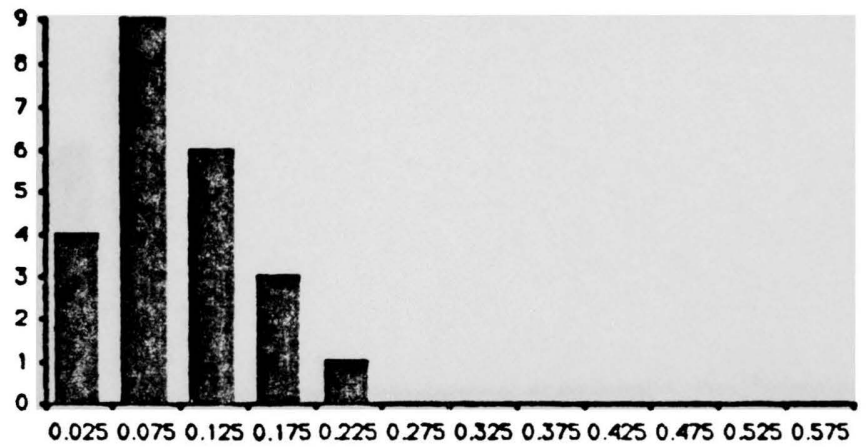

At Breakpoint

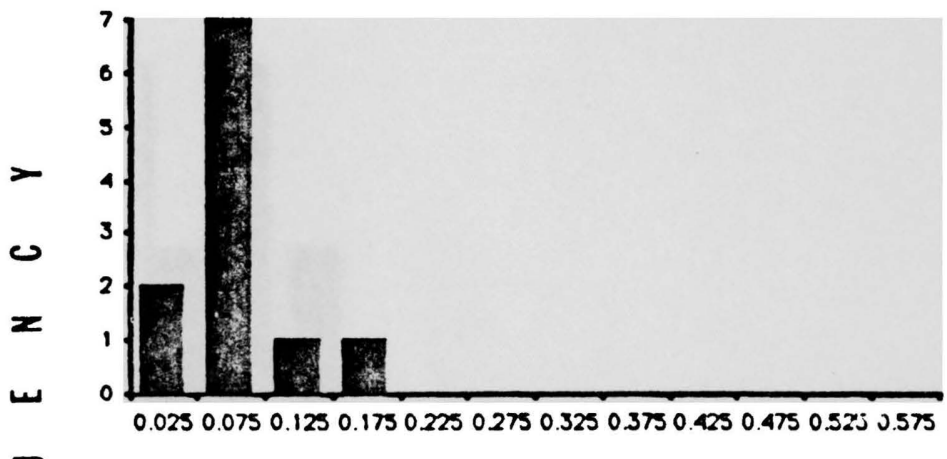

After Breakpoint

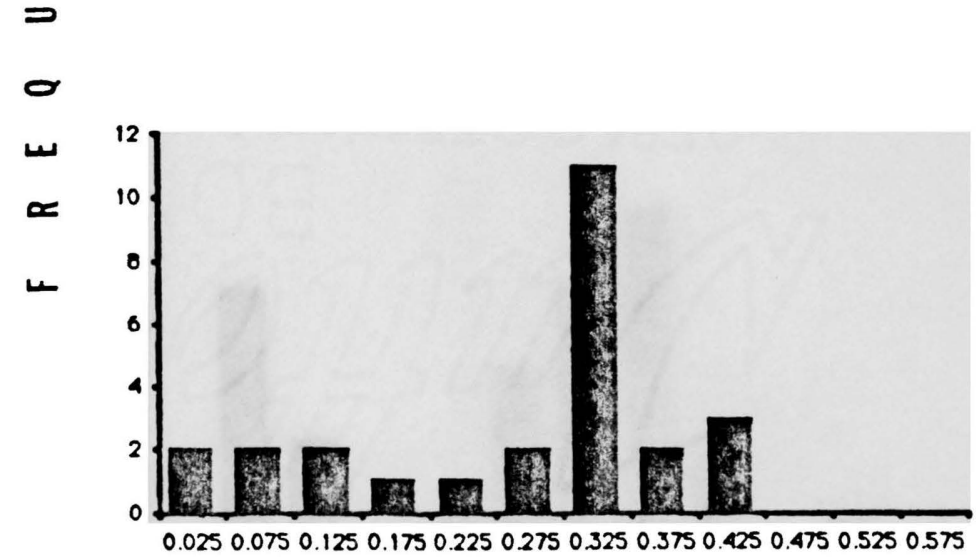

Rate Constant (/mole/L/s $\times 10^{-9}$ )

Figure 5. Frequency Distribution of Chloroform Rates of Formation at pH 7 . 
CHLOROFORM PH 9

Before Breakpoint

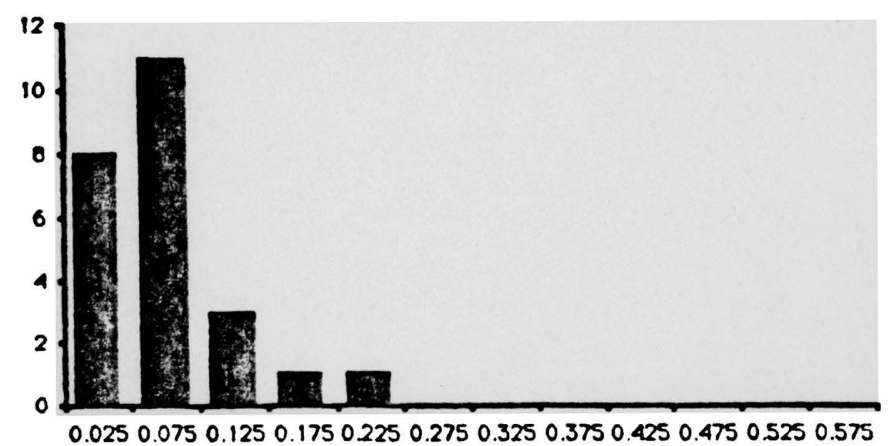

At Breakpoint

After Breakpoint

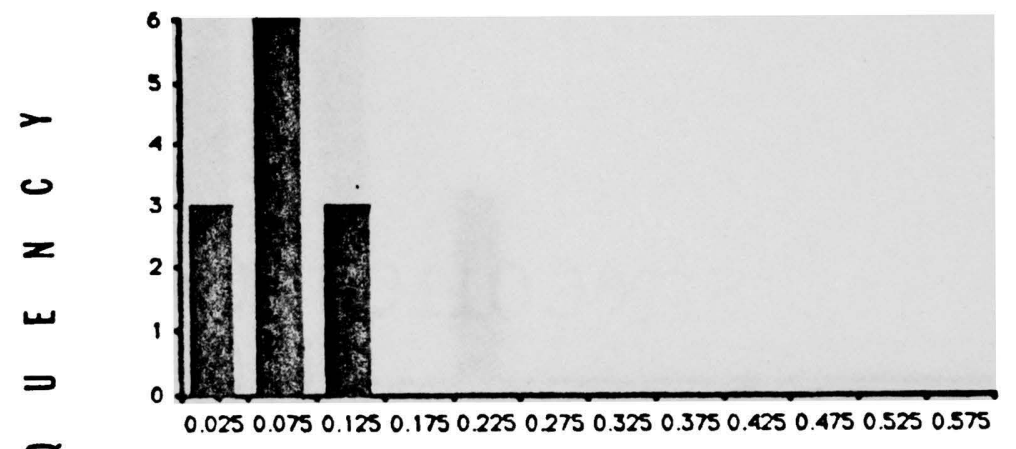

$\circ$

$\propto$

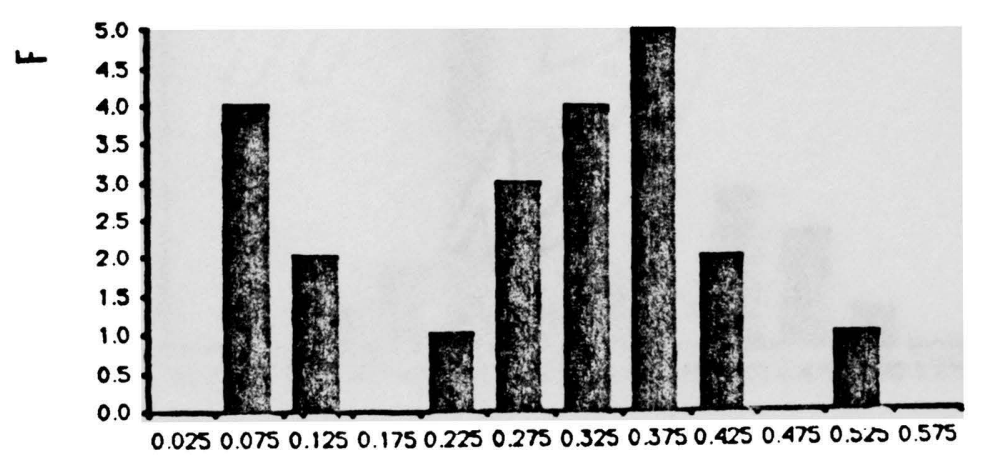

Rate Constant (/mole/L/s $\times 10^{-9}$ )

Figure 6. Frequency Distribution Chloroform Rates of Reaction at $\mathrm{pH} 9$. 


\section{BROMODICHLOROMETHANE PH7}

Before Breakpoint

At Breakpoint

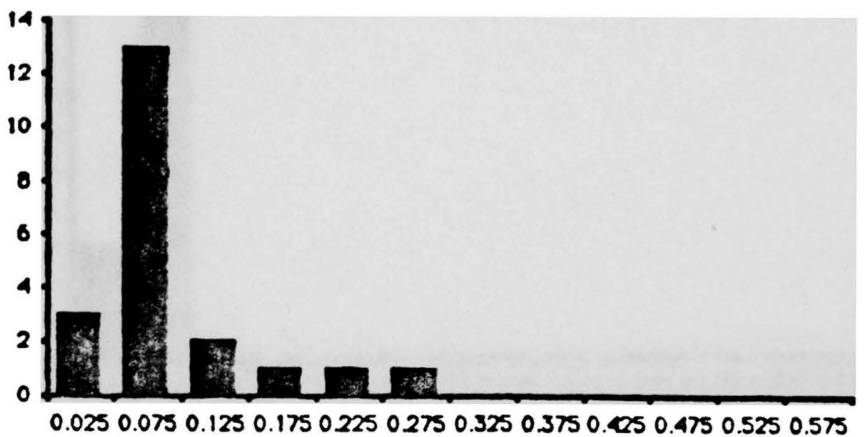

After Breakpoint

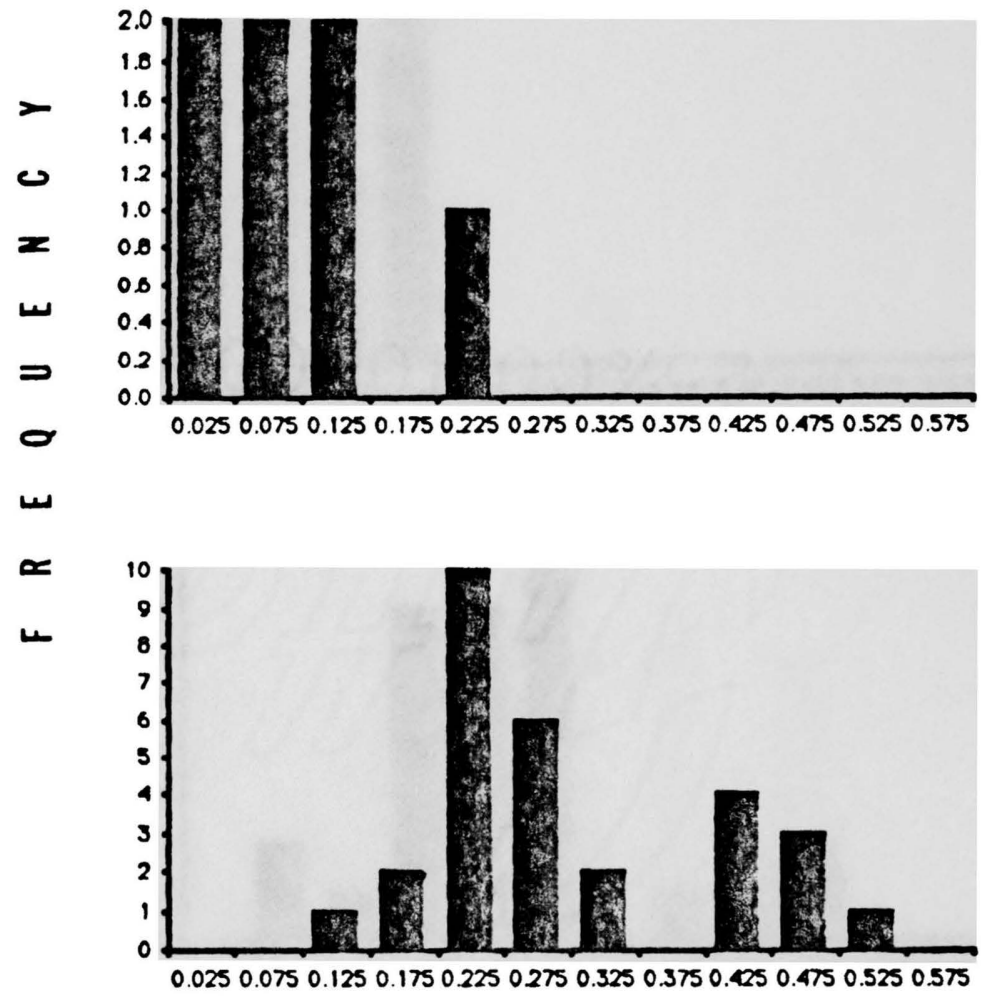

Rate Constant (/mole/L/s $\times 10^{-9}$ )

Figure 7. Frequency Distribution Bromodichloromethane Rates of Reaction at pH 7 . 


\section{BROMODICHLOROMETHANE PH9}

Before Breakpoint

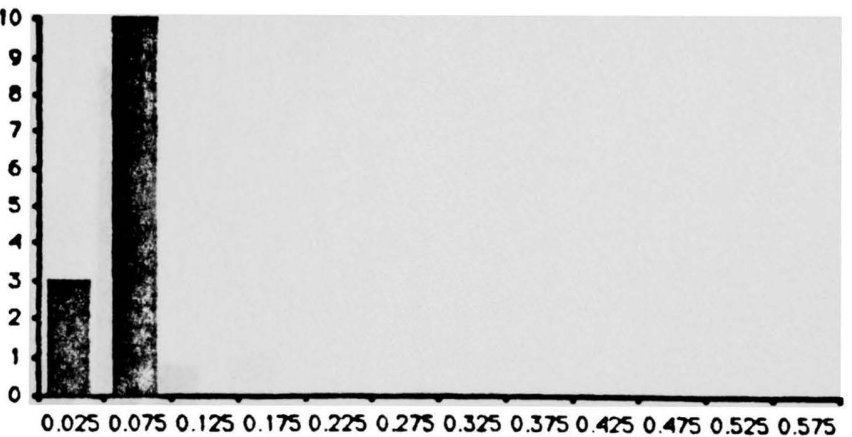

At Breakpoint

After Breakpoint

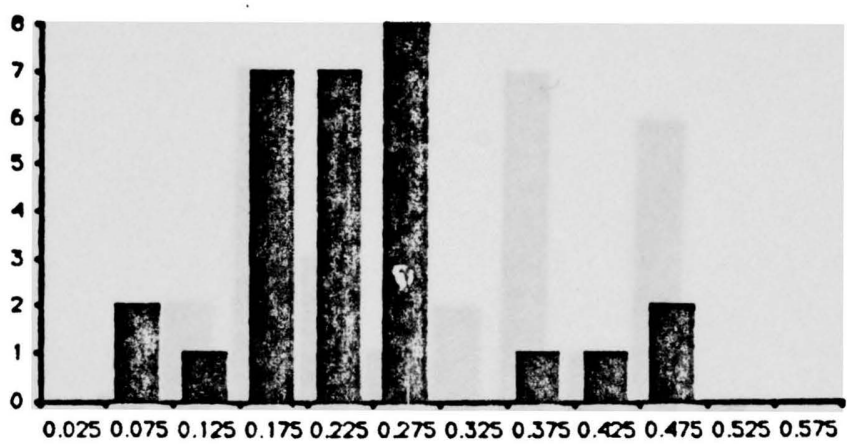

Rate Constant (/mole/L/s $\times 10^{-9}$ )

Figure 8. Frequency Distribution of Bromodichloromethane Rates of Reaction at pH 9. 


\section{DIBROMOCHLOROMETHANE PH7}

Before Breakpoint

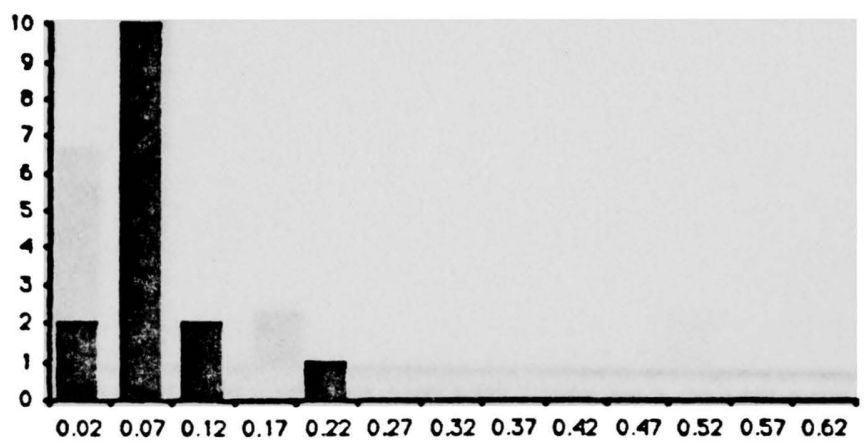

At Breakpoint

After Breakpoint

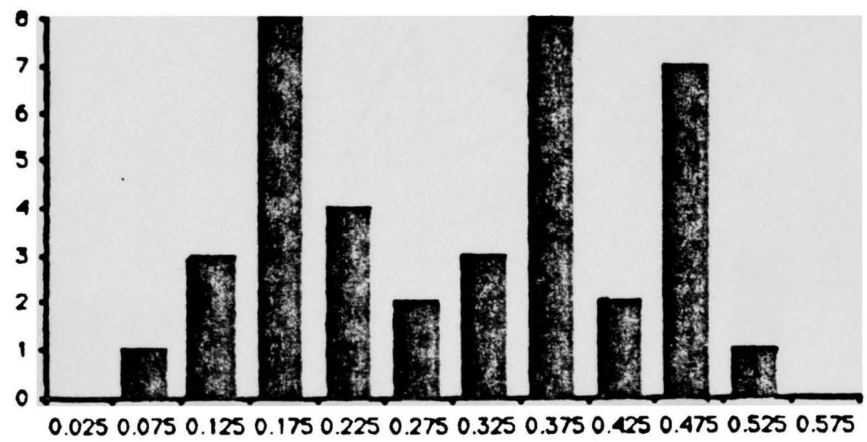

Rate Constant (/mole/L/s $\times 10^{-9}$ ) 


\section{DIBROMOCHLOROMETHANE PH 9}

\section{Before Breakpoint}

\section{At Breakpoint}

\section{After Breakpoint}
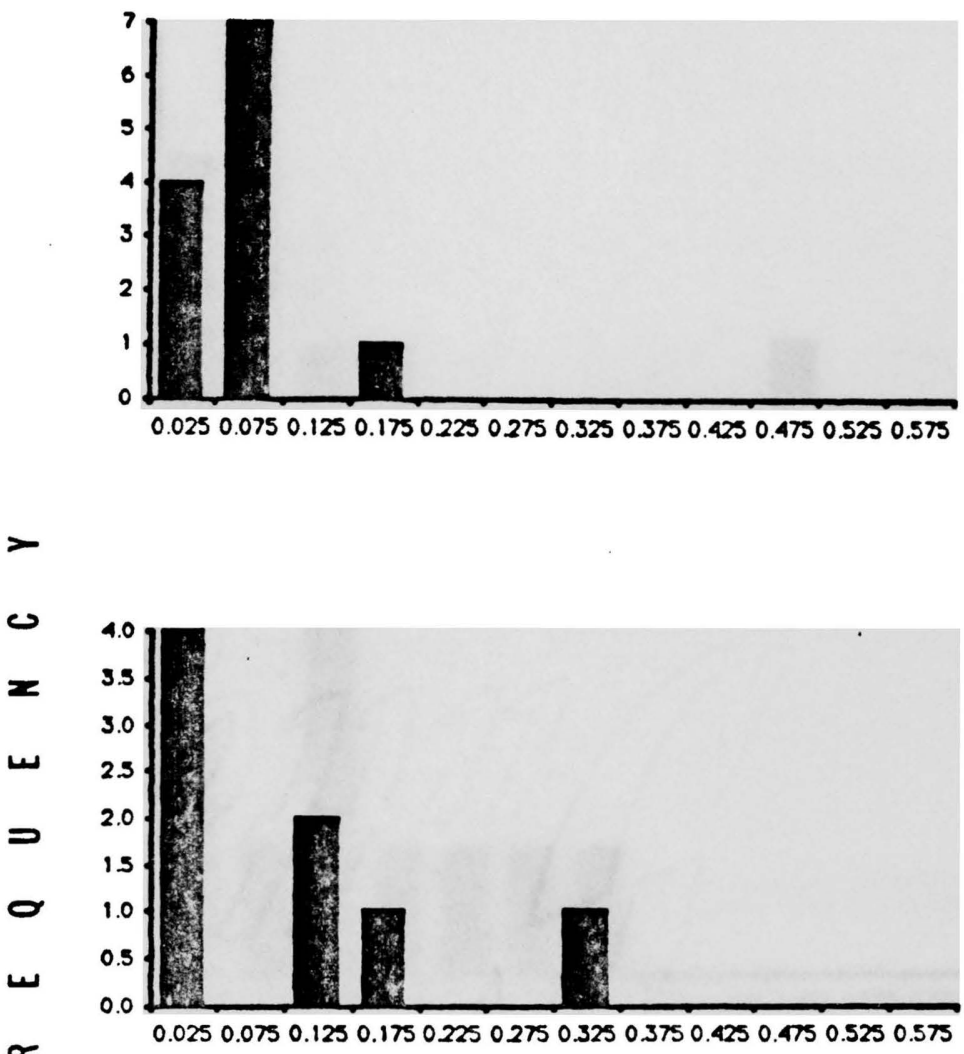

$\propto$

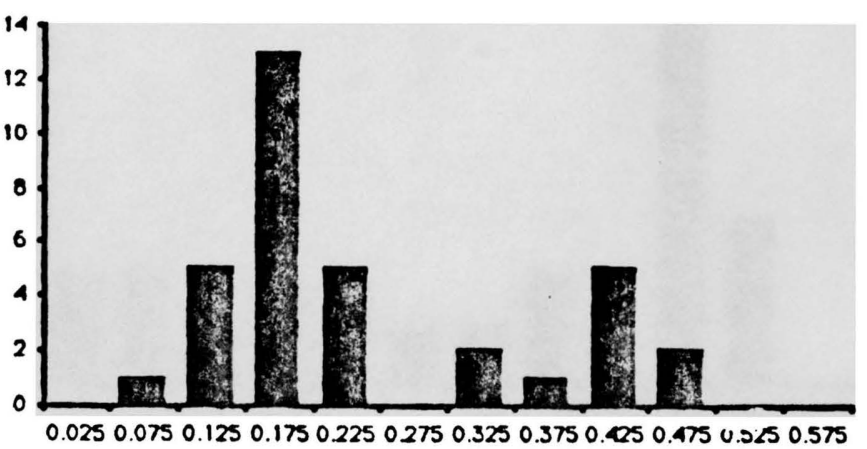

Rate Constant (/mole/L/s $\times 10^{-9}$ ) 


\section{BROMOFORM PH7}

Before Breakpoint

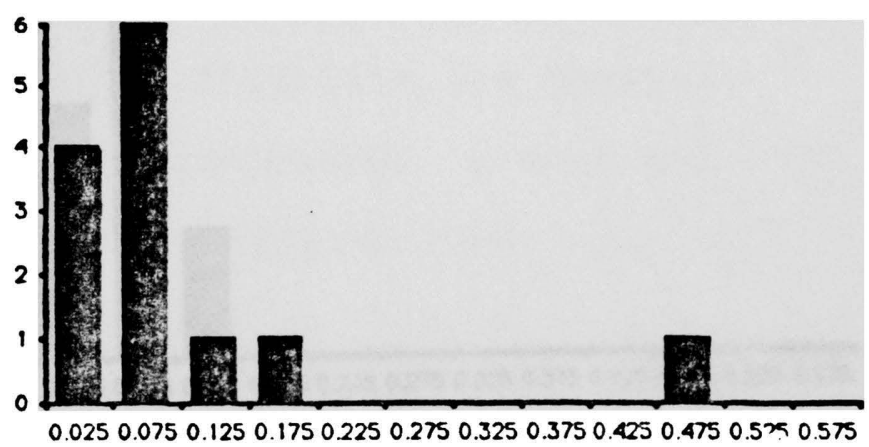

At Breakpoint

After Breakpoint

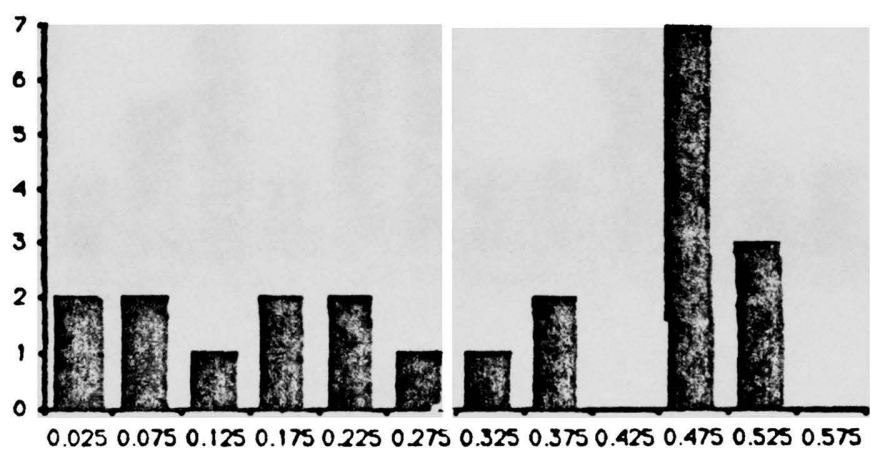

Rate Constant (/mole/L/s $\times 10^{-9}$ )

Figure 11. Frequency Distribution of Bromoform Rates of Reaction at $\mathrm{pH} 7$. 


\section{B ROMOFORM PH 9}

Before Breakpoint

\section{At Breakpoint}

After Breakpoint
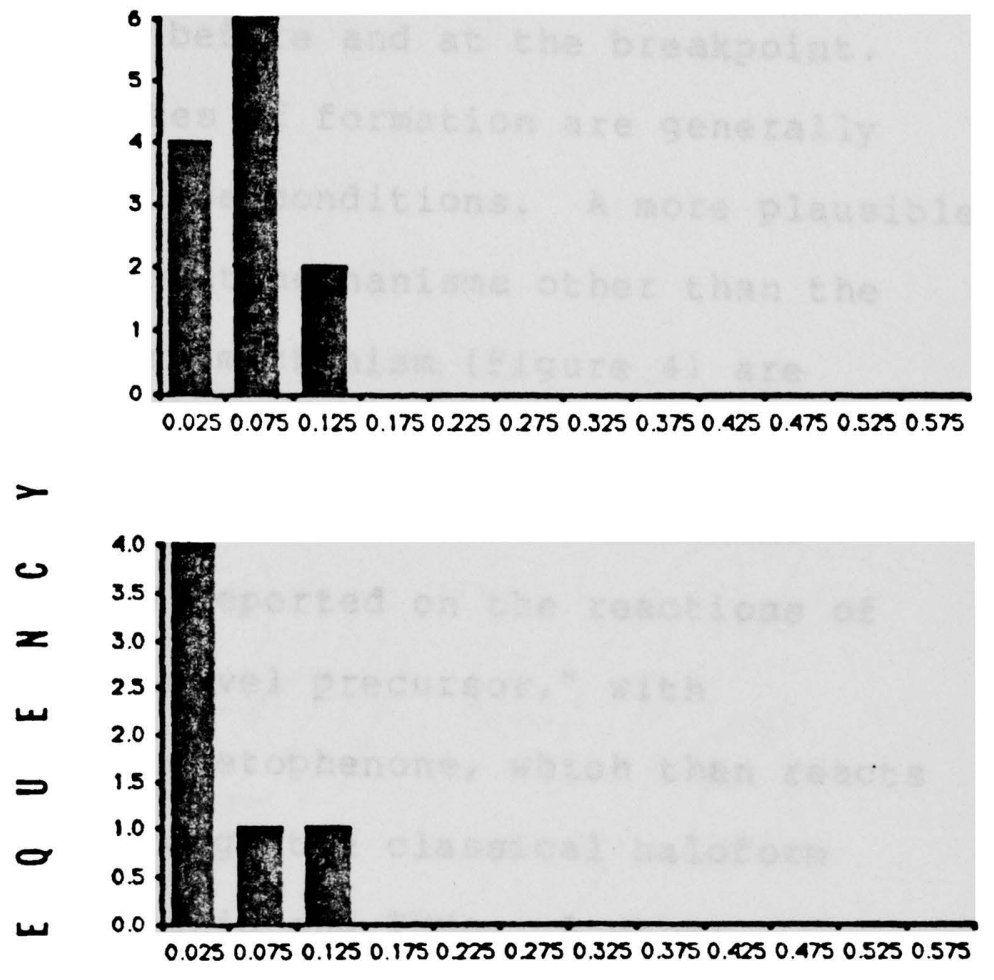

둔

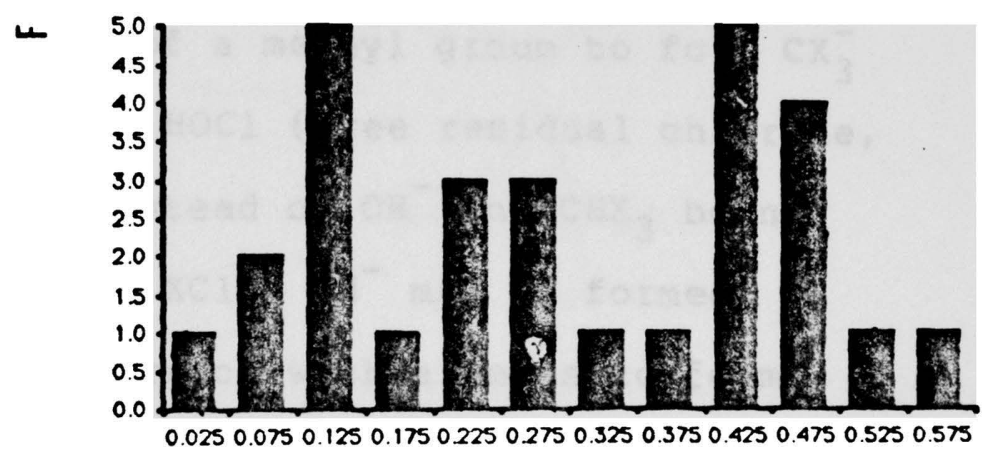

Rate Constant (/mole/L/s $\times 10^{-9}$ )

Figure 12. Frequency Distribution of Bromoform Reaction Rates at $\mathrm{pH} 9$. 
fundamentally correct, one would expect scatter even for the experiments performed before and at the breakpoint. This is not the case. Rates of formation are generally tightly clustered under these conditions. A more plausible explanation is that different mechanisms other than the generally proposed haloform mechanism (Figure 4) are occurring. Slow rate constants may be due to following multi-step reactions prior to the haloform reaction. Cooper, et al., (1983) has reported on the reactions of $\alpha$-methyl-benzlamine, "a novel precursor," with hypochlorous acid to form acetophenone, which then reacts with hypochlorous acid through the classical haloform reaction to yield benzoic acid and THMs. Another possibility is that a dual mechanism is present (Figure 13). After halogenation of a methyl group to form $\mathrm{Cx}_{3}^{-}$ and in presence of excess HOCl (free residual chlorine, i.e. after breakpoint) instead of $\mathrm{OH}^{-}$and $\mathrm{CHX}_{3}$ being formed, the carbene $\mathrm{Cx}_{3}^{-}+\mathrm{XCl}+\mathrm{OH}^{-}$may be formed. The carbene will readily react with alkenes to form halogenated cyclopropanes. Thus lower yields of THMs in some experiments will result the data on rate constants will be spread. The present mechanism can explain the results in the following manner in the first case, before the breakpoint, all HOCl is used up to forming halamines and chlorinated organics including THMs. In the second case at the breakpoint, HOCl is used up to and again 


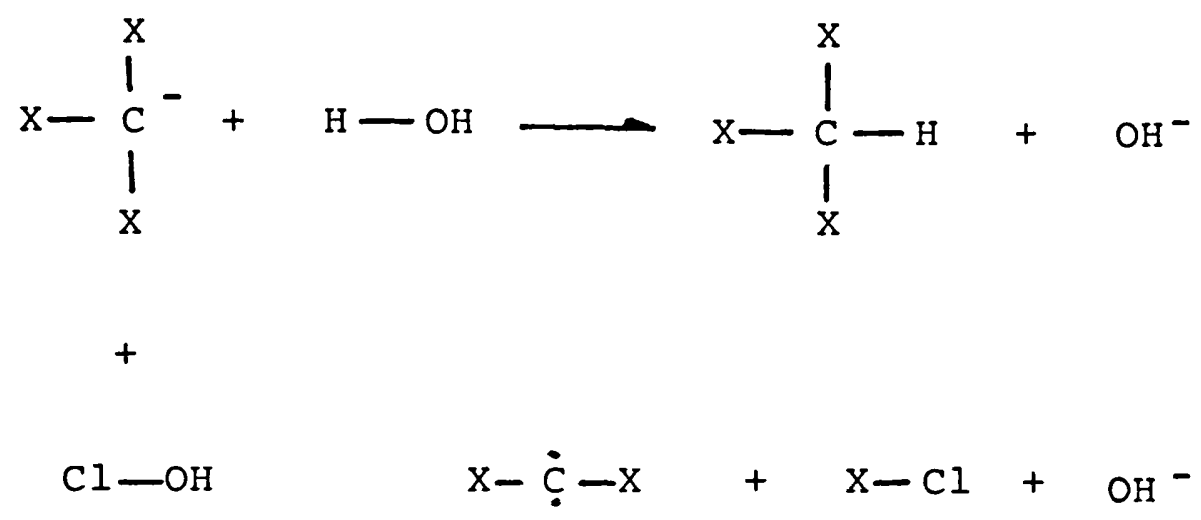

\section{CARBENE}

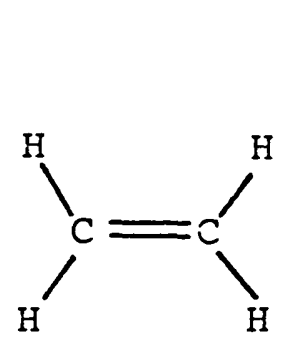

ALKENE

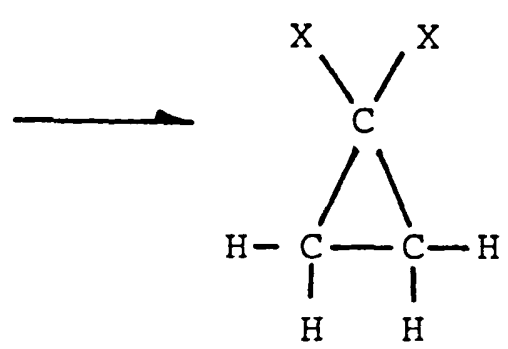

HALOGENATED CYCLOPROPANE

Figure 13. Reaction Pathway Leading to the Formation of Halogenated Cyclopropane 
halamines and chlorinated organics are formed. In the last case after the breakpoint excess HOCl is present and a dual mechanism one forming THMs the other forming a reactive carbene may occur. 
39

CONCLUSIONS

Overall kinetic rates of formation have been determined for the four individual THM species, chloroform, bromoform, bromodichloromethane and dibromochloromethane. Rates of long term formation are not as profoundly affected by $\mathrm{pH}$ as short term reaction rates. A dual pathway for the reaction of oxidant and precursor may be present and lead to the formation of carbine instead of trihalomethanes. 


\section{RECOMMENDATIONS FOR FUTURE RESEARCH}

With the overall rates of formation, reaction pathway and equations appearing in Appendix II, an investigation to formulate a predictive model based on purely kinetic arguments should be undertaken. Laboratory experiments to determine if halogenated cyclopropanes and/or similar products are formed after the breakpoint during water chlorination should be conducted. 
APPENDIX I

Derivation of the THM power function

$$
\ln [\mathrm{THM}]=k \ln (t)+B
$$

Identity:

$$
k \ln (t)=\ln (t)^{k}
$$

Substituting:

$$
\ln [T H M]=\ln (t)^{k}+B
$$

Raising to base $e: e^{\ln [\text { THM] }}=$

$$
\left.e^{\left[\ln (t)^{k}\right.}+B\right]
$$

Rewriting:

$$
e^{\ln (T H M)}=e^{\ln (t)^{k}} \times e^{B}
$$

Simplifying:

$[$ THM $]=e^{B}(t)^{k}$

Substituting :

$C=e^{B}$

Therefore:

$$
[T H M]=C(t)^{k}
$$

where:

$$
\begin{aligned}
& C=e^{B} \\
& {[T H M]=\text { concentration of } T H M} \\
& k=\text { slope } \\
& B=y \text { intercept }
\end{aligned}
$$


APPENDIX II

In reviewing data of THM formation, it was possible to organize reactions into a coherent pathway (Figure A.II.1). The result is that a series of differential equations representing the kinetics of the reactions can be written. These equations can be solved at steady state using numerical integration or other techniques. A numerical solution of the set of simultaneous equation could be used to evaluate the impact of changes in input variables on THM yields (Casey, 1984).

The following is a listing of equations used as a basis for the reaction pathway, references for each equation, the differential equations to be solved and reaction rate constants. It is hoped that this pathway and the compilation of differential equations can be used by the modeling community as a basis for a synoptic model of THM formation in treatment process. 


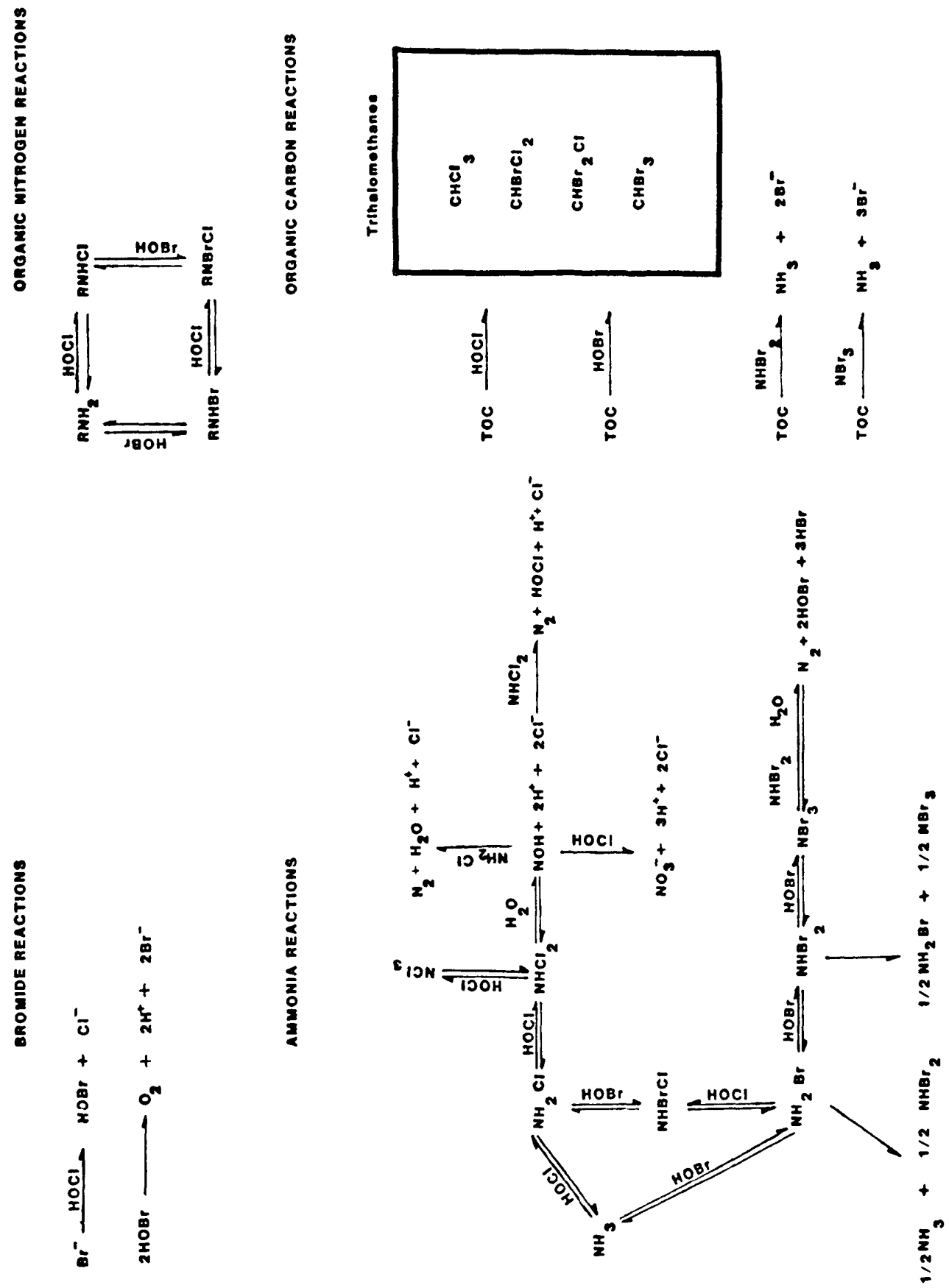

Figure A.II.l The Reactions of Aqueous Chlorine 
TABLE II.I. EQUATIONS USED TO FORUMALTE THE THM REACTION PATHWAY

Equation \#

1

2

3

4

5

6

7

8

9

10

11

12

13

14

15

16
Reaction

$\mathrm{NH}_{3}+\mathrm{HOCl} \frac{\mathrm{kl}}{\frac{\mathrm{k}-1}{\mathrm{NH}_{2}} \mathrm{Cl}}+\mathrm{H}_{2} \mathrm{O}$

$\mathrm{NH}_{2} \mathrm{Cl}+\mathrm{HOCl} \frac{\mathrm{k} 2}{\mathrm{k}-2} \mathrm{NHCl}_{2}+\mathrm{H}_{2} \mathrm{O}$

$\mathrm{RNH}_{2}+\mathrm{HOCl} \frac{\mathrm{k} 3}{\mathrm{k}-3} \mathrm{RNHCl}+\mathrm{H}_{2} \mathrm{O}$

$\mathrm{Br}^{-}+\mathrm{HOCl} \stackrel{\mathrm{k} 4}{\mathrm{HOBr}}+\mathrm{Cl}^{-}$

$\mathrm{NH}_{3}+\mathrm{HOBr} \frac{\mathrm{k} 5}{\frac{k-5}{-5}} \mathrm{NH}_{2} \mathrm{Br}+\mathrm{H}_{2} \mathrm{O}$

$\mathrm{NH}_{2} \mathrm{Br}+\mathrm{HOBr} \frac{\mathrm{k} 6}{\mathrm{k}-6} \mathrm{NHBr}_{2}+\mathrm{H}_{2} \mathrm{O}$

$\mathrm{NHBr}_{2}+\mathrm{HOBr} \frac{\mathrm{k} 7}{\mathrm{k}-7} \mathrm{NBr}_{3}+\mathrm{H}_{2} \mathrm{O}$

$\mathrm{NHBr} 2+\mathrm{NBr}_{3}+2 \mathrm{H}_{2} \mathrm{O} \stackrel{\mathrm{k} 8}{\longrightarrow} \mathrm{N}_{2}$

$+2 \mathrm{HOBr}+3 \mathrm{HBr}$

$\mathrm{RNH} \mathrm{r}_{2}+\mathrm{HOBr} \frac{\mathrm{k} 9}{\mathrm{k}-9} \mathrm{RNHBr}+\mathrm{H}_{2} \mathrm{O}$

$\mathrm{NH}_{2} \mathrm{Cl}+\mathrm{HCBr} \frac{\mathrm{klO}}{\mathrm{k}-10} \mathrm{NHBrCl}+\mathrm{H}_{2} \mathrm{O}$

$\mathrm{RNHCl}+\mathrm{HOBr} \frac{\mathrm{kll}}{\mathrm{k}-\mathrm{II}} \mathrm{RNBrCl}+\mathrm{H}_{2} \mathrm{O}$

$\mathrm{Br}^{-}+2 \mathrm{NH}_{2} \mathrm{Cl} \mathrm{kl}_{3} \mathrm{NHBrCl}+\mathrm{NH}_{3}$

$\mathrm{NH}_{2} \mathrm{Br}+\mathrm{HOCl} \frac{\mathrm{kl} 3}{\mathrm{k}-13} \mathrm{NHBrCl}+\mathrm{H}_{2} \mathrm{O}$

$\mathrm{RNHBr}+\mathrm{HOCl} \mathrm{kl4} \mathrm{RNBrCl}+\mathrm{H}_{2} \mathrm{O}$

$2 \mathrm{NH}_{2} \mathrm{Br}+\frac{\mathrm{k} 15}{\mathrm{k}-15} \mathrm{NH}_{3}+\mathrm{NBr} 3$

$$
2 \mathrm{NHBr}_{2}+\frac{\mathrm{k} 16}{\mathrm{k}-16} \mathrm{NH}_{2} \mathrm{Br}+\mathrm{NBr} 3
$$

$\mathrm{TOC}+\mathrm{HOCl} \mathrm{kIT} \mathrm{Cl}-$

Reference

\section{)}


TABLE II.1. (cont.)

Equation \#

$18 \mathrm{TOC}+\mathrm{HOBr} \stackrel{\mathrm{k} 18}{\mathrm{Br}^{-}}$

$19 \mathrm{TOC}+\mathrm{NHBr}_{2} \stackrel{\mathrm{kl9}}{\longrightarrow} \mathrm{NH}_{3}+2 \mathrm{Br}^{-}$

$20 \mathrm{TOC}+\mathrm{NBr} 3 \stackrel{\mathrm{k} 20}{\mathrm{NH}_{3}+3 \mathrm{Br}^{-}}$

$212 \mathrm{HOBr} \stackrel{\mathrm{k} 2 \mathrm{l}}{\mathrm{O}} \mathrm{O}_{2}+2 \mathrm{H}^{+}+2 \mathrm{Br}^{-}$

$22 \mathrm{NHCl}_{2}+\mathrm{HOCl} \frac{\mathrm{k} 22}{\mathrm{k}-22} \mathrm{NHCl}_{3}+\mathrm{H}_{2} \mathrm{O}$

$23 \mathrm{NHCl}_{2}+\mathrm{H}_{2} \mathrm{O} \stackrel{\mathrm{k} 23}{\longrightarrow} \mathrm{NOH}+2 \mathrm{H}++2 \mathrm{Cl}^{-}$

$24 \mathrm{NOH}+\mathrm{NH}_{2} \mathrm{Cl} \stackrel{\mathrm{k} 24}{\mathrm{~N}_{2}}+\mathrm{H}_{2} \mathrm{O}+\mathrm{H}^{+}+\mathrm{Cl}^{-}$

$25 \mathrm{NOH}+\mathrm{NHCl}_{2} \stackrel{\mathrm{k} 25}{\mathrm{~N}_{2}}+\mathrm{HCCl}+\mathrm{H}^{+}+\mathrm{Cl}^{-}$

$26 \mathrm{NOH}+2 \mathrm{HOCl}_{2} 26 \mathrm{NO}_{\overline{3}}+3 \mathrm{H}^{+}+2 \mathrm{Cl}^{-}$

$272 \mathrm{NBr}_{3}+\mathrm{OBr}^{-} \stackrel{\mathrm{k} 27}{\longrightarrow} \mathrm{N}_{2}+3 \mathrm{Br}^{-}+3 \mathrm{H}_{2} \mathrm{O}$

$282 \mathrm{NBr}_{3}+3 \mathrm{H}_{2} \mathrm{O} 228 \mathrm{~N}_{2}+3 \mathrm{HOBr}+3 \mathrm{H}^{+}+3 \mathrm{Br}^{-}(\mathrm{B})$

$\underline{\text { Reference }}$
(A) = Saunier \& Selleck (1979)
(B) = Johnson \& Qualls (1983) 
TABLE II.2. RATE CONSTANTS FOR REACTIONS IN TABLE II.I

Equation \#

1

2

3

4

5

6

7

8

9

10

11

12

13

14

15

16

17

18
Constant

Designation

$$
k 1
$$$$
k-1
$$

$k 2$

$k-2$

k 3

$k-3$

k 4

$k 5$

$k-5$

$k 6$

$k-6$

k 7

$k-7$

k 8

k 9

$k-9$

k 10

$k-10$

kll

$k-11$

$k 12$

$k 13$

k 14

$k 15$

$k-15$

$k 16$

$k-10$

$k 17$

$k 18$
Constant

Value

$1.2 \times 10^{4} \mathrm{M}^{-1} \mathrm{~S}^{-1}$

$1.28 \times 101 \mathrm{M}^{-1} \mathrm{~S}^{-1}$

$6.5 \times 10^{-7} \mathrm{~s}^{-1}$

$6.8 \times 10^{5} \mathrm{M}^{-1} \mathrm{~S}^{-1}$

$1.6 \times 10^{-6} \mathrm{~s}^{-1}$

$1.41 \times 10^{2} \mathrm{M}^{-1} \mathrm{~S}^{-1}$

$2.58 \times 10^{7} \mathrm{M}^{-1} \mathrm{~S}^{-1}$

$1.5 \times 10^{-3} \mathrm{~s}^{-1}$

$7.0 \times 10^{5} \mathrm{~m}^{-1} \mathrm{~s}^{-1}$

$7.31 \times 10^{-1} \mathrm{~s}^{-1}$

$2.5 \times 10^{4} \mathrm{M}^{-1} \mathrm{~S}^{-1}$

$5.0 \times 10^{-3} \mathrm{~s}^{-1}$

$5.9 \times 1010 \mathrm{M}^{-2} \mathrm{~s}^{-1}$

$2.0 \times 10^{4} \mathrm{M}^{-1} \mathrm{~S}^{-1}$
$7.0 \times 10^{-7} \mathrm{~S}^{-1}$

$5.0 \times 10^{3} \mathrm{M}^{-1} \mathrm{~s}^{-1}$

$2.0 \times 10^{-4} \mathrm{~s}^{-1}$

$1.0 \times 10^{4} \mathrm{M}^{-1} \mathrm{~s}^{-1}$

$7.0 \times 10^{-7} \mathrm{~s}^{-1}$

$2.8 \times 10^{6} \mathrm{M}^{-2} \mathrm{~s}^{-1}$

$2.0 \times 101 \mathrm{M}^{-1} \mathrm{~s}^{-1}$

$1.0 \times 10^{2} \mathrm{~m}^{-1} \mathrm{~s}^{-1}$

$1.0 \times 106 \mathrm{~m}^{-1} \mathrm{~s}^{-1}$

$1.0 \times 10^{5} \mathrm{~m}^{-1} \mathrm{~s}^{-1}$

$1.0 \times 105 \mathrm{M}-1 \mathrm{~s}-1$

$1.0 \times 104 \mathrm{M}^{-1} \mathrm{~S}-1$

$5.0 \times 10^{3} \mathrm{~m}^{-1} \mathrm{~s}^{-1}$

$2.0 \times 10^{4} \mathrm{~m}^{-1} \mathrm{~s}^{-1}$ 
年

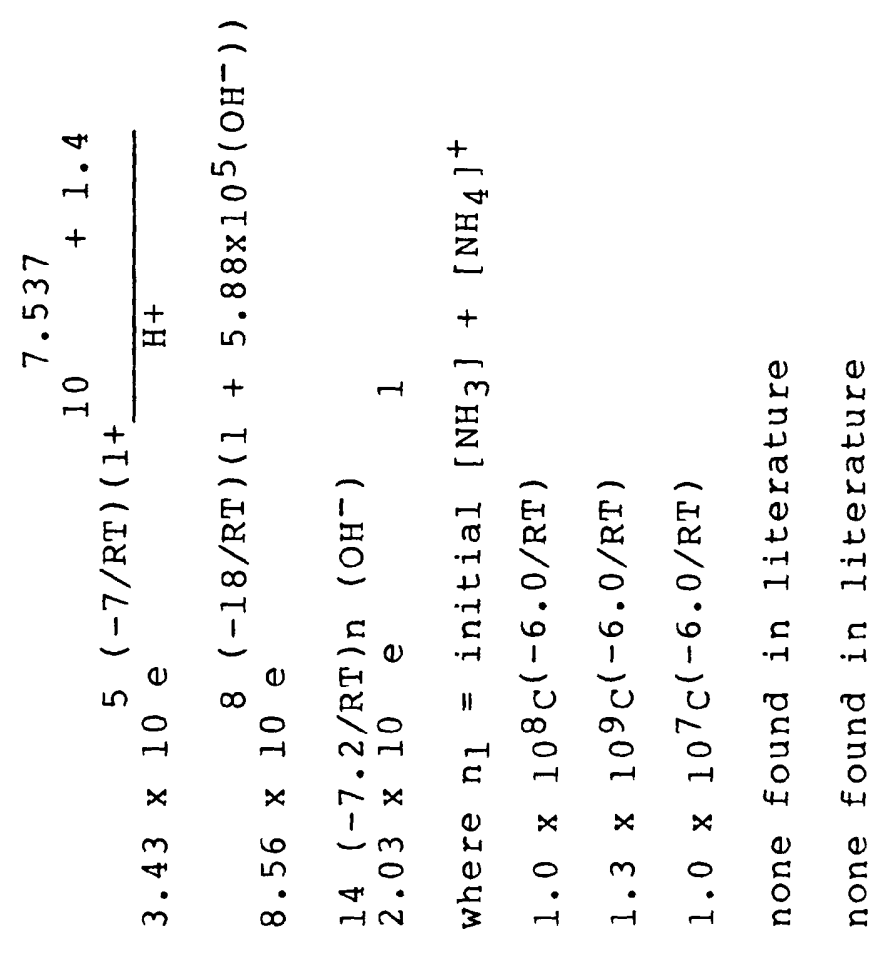

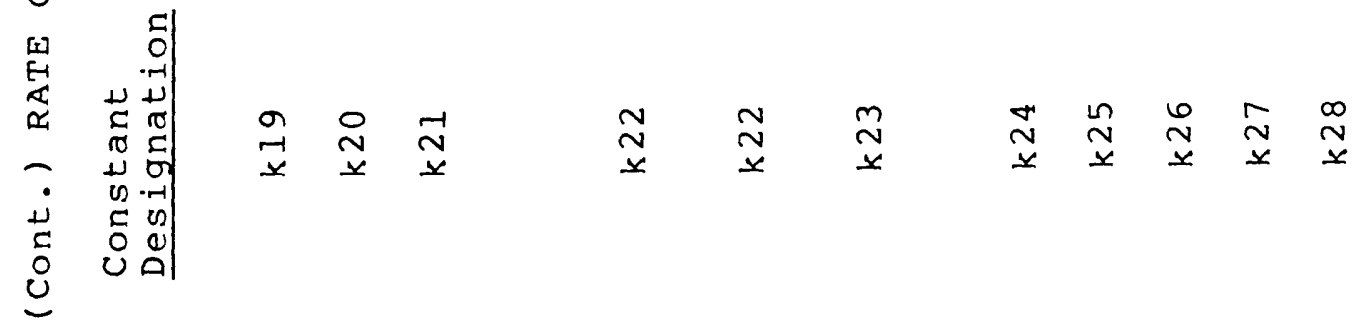

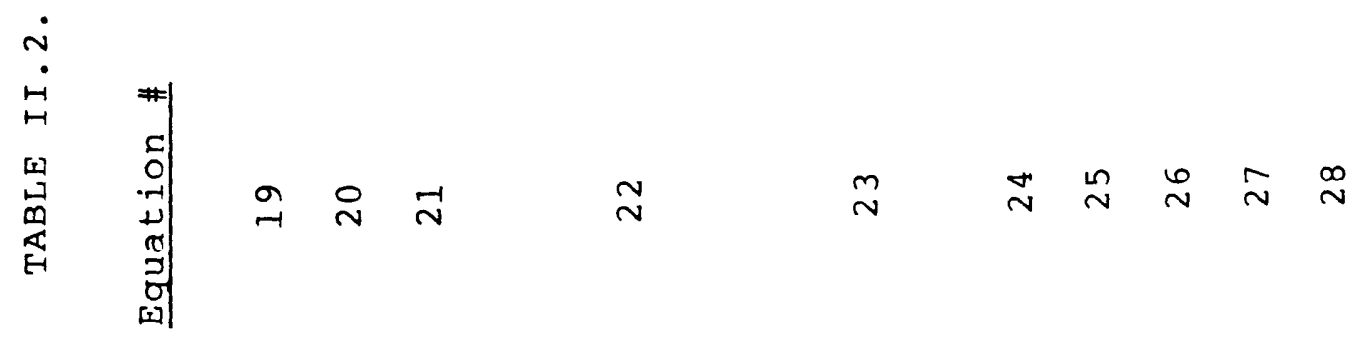


TABLE II.3. MODEL DIFFERENTIAL EQUATIONS FOR THE TRIHALOMETHANE REACTION PATHWAY IN FIGURE II.I BASED ON WORK OF HAAG \& LIETZKE

Equation \#

1 .

2

3

4

5

6
Equation

$\mathrm{d}[\mathrm{HOCl}] / \mathrm{dt}=\mathrm{kl}\left[\mathrm{NH}_{3}\right][\mathrm{HOCl}]+\mathrm{k}-1$

$\left[\mathrm{NH}_{2} \mathrm{Cl}\right]-\mathrm{k}_{2}\left[\mathrm{NH}_{2} \mathrm{Cl}\right][\mathrm{HOCl}]+k-2$

$\left[\mathrm{NHCl}_{2}\right]-k 3\left[\mathrm{RNH}_{2}\right][\mathrm{HOCl}]+k-3[\mathrm{RNHCl}]$

$-\mathrm{k}_{4}\left[\mathrm{Br}^{-}\right]\left[\mathrm{HOCl}^{2}-\mathrm{kl} 3\left[\mathrm{NH}_{2} \mathrm{Br}\right][\mathrm{HOCl}]-\right.$

$k 17$ [ $\mathrm{TOC}][\mathrm{HOCl}]-\mathrm{H}_{22}\left[\mathrm{NHCl}_{2}\right][\mathrm{HOCl}]+$

$k-22\left[\mathrm{NCl}_{3}\right]+k 25[\mathrm{NOH}]\left[\mathrm{NHCl}_{2}\right]-$ $k 26([\mathrm{NOH}])(2)$ [HOCl] $)$

$d[\mathrm{HOBr}] / \mathrm{dt}=\mathrm{k} 4\left[\mathrm{Br}^{-}\right][\mathrm{HOCl}]-\mathrm{ks}$

[ $\left.\mathrm{NH}_{3}\right][\mathrm{HOBr}]+k-5\left[\mathrm{NH}_{2} \mathrm{Br}\right]-\mathrm{k} 6$

$\left[\mathrm{NH}_{2} \mathrm{Br}\right][\mathrm{HOBr}]+\mathrm{H}^{2}\left[\mathrm{NHBr}_{2}\right]-\mathrm{H}_{7}$

$[\mathrm{NHBr} 2][\mathrm{HOBr}]+\mathrm{k} 7[\mathrm{NBr} 3]+\mathrm{k} 8$

$1 / 2\left(\left[\mathrm{NHBr}_{2}\right]\left[\mathrm{NBr}_{3}\right]\left[\mathrm{H}_{2} \mathrm{O}\right]\right)-\mathrm{k} 9$

$\left[\mathrm{RNH}_{2}\right][\mathrm{HOBr}]+\mathrm{k}-9[\mathrm{RNHBr}]-10\left[\mathrm{NH}_{2} \mathrm{Cl}\right]$

$[\mathrm{HOBR}]+k-10[\mathrm{NHBrCl}]-\mathrm{k} 11$ [RNHCl] [HOBr]

$+k-11[\mathrm{RNBrCl}]-k 19$ [TOC] [HOBr] - k21

$(2[\mathrm{HOBr}])+\mathrm{k} 28\left(2 / 3[\mathrm{NBr} 3]\left[\mathrm{H}_{2} \mathrm{O}\right]\right.$

$\left.d\left[\mathrm{NH}_{3}\right] / d t=k\right]\left[\mathrm{NH}_{3}\right][\mathrm{HOCl}]+\mathrm{k}-1$

$\left[\mathrm{NH}_{2} \mathrm{Cl}\right]-k 5\left[\mathrm{NH}_{3}\right][\mathrm{HOBr}]+k-5$

$\left[\mathrm{NH}_{2} \mathrm{Br}\right]+\mathrm{k} 12\left[\mathrm{Br}^{-}\right] 2\left[\mathrm{NH}_{2} \mathrm{Cl}\right]+\mathrm{kl} 22$

$\left[\mathrm{NH}_{2} \mathrm{Br}\right]-k-15\left[\mathrm{NH}_{3}\right]\left[\mathrm{NBr}_{3}\right]+\mathrm{k} 19$

$[\mathrm{TOC}]\left[\mathrm{NHBr}_{2}\right]+\mathrm{k}_{20}$ [ $\left.\mathrm{TOC}\right]\left[\mathrm{NBr}_{3}\right]$

$\mathrm{d}\left[\mathrm{NH}_{2} \mathrm{Cl}\right] / \mathrm{dt}=-\mathrm{k}_{2}\left[\mathrm{NH}_{2} \mathrm{Cl}\right][\mathrm{HOCl}]+\mathrm{k}-2$

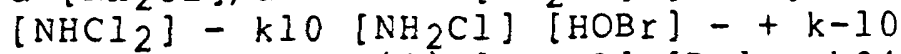

$[\mathrm{NHBrCl}]-\mathrm{k} 12(2)\left[\mathrm{NH}_{2} \mathrm{Cl}\right][\mathrm{Br}]-\mathrm{k} 24$

$[\mathrm{NOH}]\left[\mathrm{NH}_{2} \mathrm{Cl}\right]+\mathrm{kI}\left[\mathrm{NH}_{3}\right][\mathrm{HOCl}]$

d $\left[\mathrm{NHCl}_{2}\right] / \mathrm{dt}=\mathrm{k} 2\left[\mathrm{NH}_{2} \mathrm{Cl}\right][\mathrm{HOCl}]-\mathrm{k}-2$

$\left[\mathrm{NHCl}_{2}\right]-\mathrm{k}_{2} 2\left[\mathrm{NHCl}_{2}\right]$ [ $\left.\mathrm{HOCl}\right]+\mathrm{k}-22$

$\left[\mathrm{NCl}_{3}\right]-\mathrm{k}_{23}\left[\mathrm{NHCl}_{2}\right]-\mathrm{k} 25[\mathrm{NOH}]$

[ $\mathrm{NHCl}_{2}$ ]

$d\left[\mathrm{NCl}_{3}\right] / d t=k 22\left[\mathrm{NHCl}_{2}\right][\mathrm{HOCl}]-\mathrm{k}-22$

[ $\mathrm{NCl}_{3}$ ] 
TABLE II.3. (cont.)

Equation \#

7

8

9

10

11

12

13

14

\section{Equation}

$d\left[\mathrm{RNH}_{2}\right] / \mathrm{dt}=\mathrm{k}_{3}\left[\mathrm{RNH}_{2}\right][\mathrm{HOCl}]+\mathrm{k}-3$

$[\mathrm{RNHCl}]+k 9\left[\mathrm{RNH}_{2}\right]$ [HOBr] $+k-9$ [RNHBr]

$\mathrm{d}\left[\mathrm{Br}^{-}\right] / \mathrm{dt}=-\mathrm{k} 4[\mathrm{Br}-][\mathrm{HOCl}]-\mathrm{k} 12$

$\left[\mathrm{Br}^{-}\right](2)\left[\mathrm{NH}_{2} \mathrm{Cl}\right]+\mathrm{k} 18$ [TOC] [HOBr]+ $k 19$ [TOC] [NHBr2] $+\mathrm{N}_{2} \mathrm{O}$ [ $\left.\mathrm{TOC}\right]\left[\mathrm{NBr}_{3}\right]+$

(2) k21 [ $\mathrm{HOBr}]+k 27$ (2) [NBr] [OBr-]+ $\begin{array}{llllll}k 28 & \text { (2) } & {\left[\mathrm{NBr}_{3}\right]} & {\left[\mathrm{H}_{2} \mathrm{O}\right]}\end{array}$

$\mathrm{d}\left[\mathrm{NH}_{2} \mathrm{Br}\right] / \mathrm{dt}-\mathrm{k}-\mathrm{s}\left[\mathrm{NH}_{3}\right][\mathrm{HOBr}]-\mathrm{k} 6$ $\left[\mathrm{NH}_{2} \mathrm{Br}\right][\mathrm{HOBr}]+\mathrm{k}-6\left[\mathrm{NHBr}_{2}\right]-\mathrm{k} 13$ $\left[\mathrm{NH}_{2} \mathrm{Br}\right][\mathrm{HOCl}]-k 15$ (2) $\left[\mathrm{NH}_{2} \mathrm{Br}\right]+k-15$ $\left[\mathrm{NH}_{3}\right]\left[\mathrm{NBr}_{3}\right]-\mathrm{k}-16\left[\mathrm{NH}_{2} \mathrm{Br}\right]\left[\mathrm{NBr}_{3}\right]$

$d\left[\mathrm{NHBr}_{2}\right] / \mathrm{dt}=\mathrm{k} 6\left[\mathrm{NH}_{2} \mathrm{Br}\right][\mathrm{HOBr}]+\mathrm{k}-6$ $\left[\mathrm{NHBr}_{2}\right]-\mathrm{k} 7$ [NHBr 2$]\left[\mathrm{HOBr}_{2}\right]+\mathrm{k}-7$ $\left[\mathrm{NBr}_{3}\right]-\mathrm{k} 8\left(\left[\mathrm{NHBr}_{2}\right]\left[\mathrm{NBr}_{3}\right][\mathrm{HO}]\right)-$ $\mathrm{k} 13\left[\mathrm{NH}_{2} \mathrm{Br}\right][\mathrm{HOCl}]-\mathrm{kl}(2)\left[\mathrm{NH}_{2} \mathrm{Br}\right]+$ $k-16\left[\mathrm{NH}_{2} \mathrm{Br}\right]\left[\mathrm{NBr}_{3}\right]-k 19$ [TOC] [NHBr 2$]$

$d\left[\mathrm{NBr}_{3}\right] / d t=k 7$ [NHBr 2$]\left[\mathrm{HOBr}_{2}\right]+\mathrm{k}-7$ [NBr 3$]-\mathrm{N}_{3}$ ([NHBr 2$]$ [NBr 3$]+\mathrm{N}_{3} \mathrm{~N}_{2}$

(2) $\left[\mathrm{NH}_{2} \mathrm{Br}\right]+k-15\left[\mathrm{NH}_{3}\right]\left[\mathrm{NBr}_{3}\right]+\mathrm{k} 16$

(2) $\left[\mathrm{NH}_{2} \mathrm{Br}\right]-\mathrm{k}-16\left[\mathrm{NH}_{2} \mathrm{Br}\right]\left[\mathrm{NBr}_{3}\right]-$ $\mathrm{k}-16\left[\mathrm{NH}_{2} \mathrm{Br}\right]\left[\mathrm{NBr}_{3}\right]-\mathrm{k}_{20} \mathrm{O}\left[\mathrm{TOC}^{2}\right]\left[\mathrm{NBr}_{3}\right]$

- k27 (2) [ $\left.\mathrm{NBr}_{3}\right]\left[\mathrm{mOBr}^{-}\right]-\mathrm{k} 28$ (2) $\left[\mathrm{NBr}_{3} \mathrm{P}(3)\right]\left[\mathrm{H}_{2} \mathrm{O}\right]$

$d[\mathrm{TOC}] / d t=k 17[\mathrm{TOC}][\mathrm{HOCl}]-k 18[\mathrm{TOC}]$ [HOBr] - k19 [TOC] [NHBr2]-k20 [TOC] $\left[\mathrm{NBr} r_{3}\right]$

$d[\mathrm{RNHCl}] / d t=k 11[\mathrm{RNHCl}][\mathrm{HOBr}]+k-11$ $[\mathrm{RNBrCl}]+k 3\left[\mathrm{RNH}_{2}\right][\mathrm{HOCl}]-k-3$ [RNHCl]

$\mathrm{d}[\mathrm{RNHBr}] / \mathrm{dt}=\mathrm{k} 14[\mathrm{RNHBr}][\mathrm{HOCl}]+\mathrm{k} 9$ [ $\left.\mathrm{RNH}_{2}\right]$ [HOBr] $-k-9$ [RNHBr] 
TABLE II.3. (Cont.)

Equation \#

15

16

17

18

19

20

\section{Equation}

$d[\mathrm{NOH}] / d t=k 23\left[\mathrm{NHCl}_{2}\right]-k 24[\mathrm{NOH}]$

$\left[\mathrm{NH}_{2} \mathrm{Cl}\right]-\mathrm{k} 26([\mathrm{NOH}])(2)$ [ $\left.\left.\mathrm{HOCl}\right]\right)-k 25$

$[\mathrm{NOH}]\left[\mathrm{NHCl}_{2}\right]$

$\mathrm{d}[\mathrm{NHBrCl}] / \mathrm{dt}=\mathrm{kl0}\left[\mathrm{NH}_{2} \mathrm{Cl}\right][\mathrm{HOBr}]-\mathrm{k}-10$ $[\mathrm{NHBrCl}]+k 12(2)\left[\mathrm{NH}_{2} \mathrm{Cl}\right][\mathrm{Br}]+\mathrm{kl} 3$ [ $\mathrm{NH}_{2} \mathrm{Br}$ ] [ $\left.\mathrm{HOCl}\right]$

$d[\mathrm{RBrCl}] / d t=k l][\mathrm{RNHCl}][\mathrm{HOBr}]-k-1]$ [RNBrCl] - kl4 [RNHBr]

$\mathrm{d}\left[\mathrm{N}_{2}\right] / \mathrm{dt}=\mathrm{k} 24[\mathrm{NOH}]\left[\mathrm{NH}_{2} \mathrm{Cl}\right]+\mathrm{k} 25[\mathrm{NOH}]$ $\left[\mathrm{NHCl}_{2}\right]+k 27(2)\left[\mathrm{NBr}_{3}\right]\left[\mathrm{OBr}^{-}\right]+\mathrm{k} 28$ (2) $\left[\mathrm{NBr}_{3}\right]\left[\mathrm{H}_{2} \mathrm{O}\right]$

$a\left[\mathrm{NCl}_{3}\right] / d t=k 22\left[\begin{array}{lll}\mathrm{NHCl}_{2}\end{array}\right][\mathrm{HOCl}]-k-22$ $\left[\mathrm{NCl}_{3}\right]$

$d\left[\mathrm{NO}_{3}^{-}\right] / d t=k 26(2)[\mathrm{NOH}][\mathrm{HOCl}]$ 
Amy, G.L., W.J. Cooper, K. Kashfian and P.H. King, 1983. A Mathematical Model for the Formation of Trihalomethanes in a Highly colored Groundwater Containing Ammonia and Bromine. Preprint Abstract, American Chemical Society, Division of Environmental Chemistry, Seattle, Washington.

Anonymous, 1980. Trihalomethanes in Drinking Water: A Guide-Answers to Your Concerns and Questions about THMs. American Water Works Association, Denver, Co.

Anonymous, 1982. Disinfection, Committee Report. J. AWWA, $74(7): 376-380,1982$.

Anderson, M.C., R.C. Butler, F.J. Holdren and B.H. Kornegay, 1981. Controlling Trihalomethanes with

Powered Activated Carbons. J. AWWA, 73(8):432-439.

Arguello, M.D., C.D. Chriswell, J.S. Fritz, L.D. Kissinger, K.W. Lee, J.J. Richard, and H.J. Svec, 1979. Trihalomethanes in Water: A Report on Seasonal Variation in concentrations, and Precursors of Trihalomethanes. J. AWWA, 71(9):504-508.

Babcock, D.B. and P.C. Singer, 1979. Chrorination and Coagulation of Humic and Fulvic Acids. J. AWWA, $71(3): 149-152$.

Belick, T.J., S.A. Tarantino and R.H. Zumstein, 1983. Methods of Adding Ammonia During Water Treatment. The Opflow (AWWA), 9(12).

Bellar, T.A. and J.J. Lichtenberg, 1979. Semiautomated Headspace Analysis of Drinking Waters and Industrial Waters for Purgeable volatile organic Compounds. Measurement of Organic pollutants in Water and Wastewater, C.E. Hanhall, Editor, ASTM, Washington, D.C. p. 109-129.

Blanck, C.A., 1979. Trihalomethane Reduction in Operating Water Treatment Plants. J. AWWA, 71(9):525-528.

Bull, R.J., 1982. Health Effects of Drinking Water Disinfectant and Disinfectant By-products. Environ. Sci. Technol. 16:554A-559A. 
Bunn, W.W., B.B. Haas, E.R. Deane, and R.D. Kleopfer, 1975. Formation of Trihalomethane by Chlorination of Surface Water. Environ. Lett., 10(1):205-213.

Carpenter, J.H. and D.L. Macalady, 1978a. Chemistry of Halogens in Seawater, Water Chlorination:

Environmental Impact and Health Effects, Volume I, Ed. R.L. Jolley, Ann Arbor Science Publishers, Ann Arbor, Michigan p. 161 .

Carpenter, J.H. and C.A. Smith, 1978b. Reactions in Chlorinated Seawater. Water Chlorination: Environmental Impact and Health Effects, Volume II, Eds. R.L. Jolley, H. Gorchev, D.H. Hamilton. Ann Arbor Science Publishers, Ann Arbor, MI p. 195.

Casey, L.S.; W.J. Cooper, and R.J. Cloud, 1984. A Predictive Kinetic Model of Trihalomethanes (THMS) in Chlorinated Groundwater. Presented at the Forty-Eight Annual Meeting of the Florida Academy of Sciences, March 29-31, 1984, Boca Raton, Florida.

Chapin, R.M., 1934. The Effect of Hydrogen Iron Concentration on the Decomposition of Hypohalites. J. Am. Chem. Soc., 56:2211-2215.

Clark, R.M., 1981. Evaluating Costs and Benefits of Alternative Disinfectants. J. AWWA, 73(2):39-93.

Colquist, J.M., and P.C. Singer, 1982. Removing Trihalomethane Precursors by Permanganate oxidation and Manganese Dioxide Absorption. J. AWWA, $74(2): 78-83$.

Cooper, W.J., and D. Kaganowicz, 1985. A Novel Precursor of Trihalomethanes. Water Chlorination: Chemistry, Environmental Impact and Health Effects, Volume V, Eds. R.L. Jolley, R.J. Bull, W.P. Davis, S. Katz, M.H. Roberts, V.A. Jacobs, Lewis Publishers Inc., Chelsea, MI.

Cooper, W.J., M.F. Mehran, R.A. Slifker and D.L. Savo_e, 1984. Elimination of Ammonia Interference in the Purge and Trap G.C. Determination of Organohalogens in Water. J. Chrom. Sci. 22:462-464, p. 285.

Cooper, W.J., L.M. Meyer, C.C. Bofill and E. Cordal, 1981a. Quantitative Effects of Bromine on the Formation and Distribution of THMs in Groundwater with a High Organic Content. Water Chlorination: Environmental Impact and Health Effects, Volume 4, 
Book 2, Eds. R. L. Jolley, W.A. Brungs, J.A. Cotruvo, R.B. Cumming, J.S. Mattice, V.A. Jacobs, Ann Arbor Science Publishers, Ann Arbor, Michigan.

Cooper, W.J., J.T. Villate, E.M. Ott, R.A. Slifker, F.Z. Parsons and G.A. Graves, 1981b. Formation of Organo halogen Compounds in Chlorinated Secondary Wastewater Effluent. Water Chlorination: Environmental Impact and Health Effects, Volume IV, Book 2, Eds. R.L. Jolley, W.A. Brungs, J.A. Cotruvo, R.B. Cumming, J.S. Mattice, V.A. Jacobs. Ann Arbor Science Publishers, Ann Arbor, MI. p. 483.

Cooper, W.J., R.G. Zika and M.S. Steinhauer, 1983. The Influence of Bromide on the Formation of Trihalomethanes During Water Treatment: Evaluation of Alternative Oxidants and Research Needs. Third Quarterly Report to USEPA Cooperative Agreement CR 810277-01, Washington, D.C.

Dean, R.B., 1981. Use of Log-Normal Statistics in Environmental Monitoring Chemistry in Water Reuse, Volume 1, W.J. Cooper, Ed. Ann Arbor Science Publishers, Ann Arbor, MI. p. 245.

Dore, M., N. Merlet and T. Blanchard, 1978. Contribution a Letude de la Determination des Conditions de Formation des Haloforms Water Research, 12(6):427-437.

Dreish, F.A., M. Grower and T.O. Munson, 1980. Survey of the Huntington and Philadelphia River Water Supplies for Purgeable Organic Contaminants. Technical Report USEPA (EPA-903/9-81-003), Region III, Central Laboratory, Anapolis, MD.

Dykes, G.M., 1980. Sampling for THMs in Florida. Proceedings of the AWWA Water Quality Technology Conference. Miami Beach, FL, December 7-10, p. 229-233.

Engerholm, B.A. and G.L. Amy, 1983. A Predictive Model For Chloroform Formation From Humic Acid. JAWWA $75: 418-422$.

Federal Register, 1979. Part IX-EPA. National Interim Primary Drinking Water Regulations: Trihalomethanes, Washington, D.C.

Feige, W.A. and J. DeMarco, 1980. Water Treatment Process Modification for Trihalomethane Control and Organic substances in the Ohio River. Technical Report 
(EPA-600/2-80-028) USEPA, Municipal Environmental Research Laboratory, Cincinnati, $\mathrm{OH}$.

Fisher, A.J. and J.S. Taylor, 1983. Prediction of THMFP, Technical Report, University of Central Florida, Civil Engineering Department, Orlando, FL.

Glaze, W.H. and J. L. Wallace, 1984 . Control of Trihalometane Precursors in Drinking Water: Granular Activated Carbon With and Without Preozonation. J. AWWA, $76(2): 68-75$.

Glaze, W.H., G.R. Peyton, R. Rawley, F. Huang and S. Lin, 1978. A Comparison of Ozone/UV for the Destruction of Refractory Organic Compounds in Water. Ozone Technology Symposium, Los Angeles, CA.

Gray, E.T., D.W. Margerum and R.P. Huffman, 1978. Chloramine Equilibra and the Kinetics of Disproportionation in Aqueous Solution. Organometals and Organometalloids Occurrence and Fate in the Envi ronment, F. Brinkman, J.M. Bellama, Editors. American Chemical Society, Washington, D.C.

Haag, W.R. and M.H. Lietzke, 1981. A Kinetic Model for Predicting the Concentrations of Active Halogen Species in Chlorinated Saline Cooling Waters. A Final Report. Technical Report, (ORNL/TM-7942) Oak Ridge National Laboratory, Oak Ridge, TN.

Hoehn, R.C., D.B. Barnes, B.C. Thompson, C.W. Randall, T.J. Grizzard and P.T.B. Shaffer, 1980. Algae as Sources of Trihalomethane Precursors. J. AWWA, 72(6):344-350.

Hoff, J.C. and E.E. Geldreich, l981. Comparison of the Biocidal Efficiency of Alternative Disinfectants. J. AWWA, 73(1):41-44.

Hubbs, S.A. 198la. The Oxidation of Haloforms and Haloform Precursors Utilizing Ozone. Technical Report. Louisville Water Company, Louisville, KY.

Hubbs, S.A.,. D. Amundsen and P.O. Lthius, 1981. Use of Chroline Doxide, Chloramines and Short Term Free Chlorination as Alternate Disinfects. J. AWWA, $73(2): 97-100 /$

Johnson, J.D., G.W. Inman and T.W. Trofe, 1982. Cooling Water Chlorination: the Kinetics of Chlorine, Bromine and Ammonia in seawater, Technical Report (NUREG/CR-1522 RE) US Nuclear Regulatory Commission, 
Division of Health, Siting and Waste Management, Washington, D.C.

Johnson, J.D. and R.G. Qualls, 1983. A Kinetic Model for the Chlorination of Power Plant Cooling Waters. Technical Report (NUREG/CR-2806 RE) US Nuclear Regulatory Commission, Divisions of Health, Siting and Waste Management, Washington, D.C.

Kashfian, K., 1984. Formation and Distribution of THMs in Chlorinated Groundwater, Masters Thesis, Florida International University, Miami, FL.

Kavanaugh, M.C., A.R. Trussell, J. Cromer and R.R. Trussell, 1980. An Empirical Kinetic Model of Trihalomethane Formation: Applications to Meet the Proposed THM Standard, J. AWWA, 72(10):578-582.

Kissinger, L.D. and J.S. Fritz, 1976. Analytical Notes Analysis of Drinking Water for Haloforms. J. AWWA, $68(8): 435-437$.

Knoppert, P.L., G. Oskam and E.G.H. Vreenburgh, 1980. An Overview of European Water Treatment Practice, J. AWWA, 72(11):592-599.

Kringstad, K.P., P.O. Lunquist, F. desousa and L.M. Stromberg, 1983. On the Formation of Mutagens in the Chlorination of Humic Acid. Environ. Sci. Technol., $17: 553-555$.

Lapointe, T.F., G. Inman and J.D. Johnson, 1975. The Kinetics of Tribromamine Decomposition. Disinfection of Water and Wastewater, Ed., J.D. Johnson. Ann Arbor Science Publishers, Ann Arbor, MI. p. 301.

Lee, K.W., J.S. Fritz and C.D. Chriswell, 1982. Haloform Precursors in Water. Technical Report, USERDA

(cont ract $\# W-7405-E N G-82$ ), Washington, D.C.

Lietzke, M.H., 1977a. A Kinetic Model for Predicting the Composition of Chlorinated Waters Discharged from Power Plant Cooling Systems. Technical Report, USNRC (ORNL/NUREG-13), Oak Ridge National Laboratory, Oak Ridge, TN.

Lietzke, M.H., 1977b. A Validation of the Kinetic Model for Predicting the Composition of Chlorinated Water Discharged from Power Plant Cooling systems. Technical Report, USNRC (ORNL/NUREG-32), Oak Ridge National Laboratory, Oak Ridge, TN. 
Luong, T.V., C.J. Peters and R. Perry, 1982. Influence of

Bromide and Ammonia Upon the Formation of

Trihalomethanes Under Water Treatment Conditions,

Environ. Sci. Technol. 16:473-479.

Macalady, D.L., J.H. Carpenter and C.A. Moore, 1977.

Sunlight Induced Bromate Formation in Chlorinated

Seawater, Science, 195:1335-1337.

Margerum, D.W., E.T. Gray and R.P. Huffman, 1978.

Chlorination and Formation of N.-Chloro Compounds in

water Treatment, Organmetals and Organometalloids

occurrence and Fate in the Envi ronment. F.E.

Brinkman, J.M. Bellama, Editors, American Chemical

Society, Washington, D.C.

McCabe, L.J., 1977. Health Effects of Organics in Drinking

Water. Proceeding of the AWWA Water Technology

Conference, Kansas City, Mo. December 4-7, 1977.

Paper \#4-2.

Mehran, M.F., R.A. Slifker and W.J. Cooper, 1984.

A Simplified Liquid-Liquid Extraction Method for

Analysis of Trihalomethanes in Drinking Water, J.

Chrom. Sci. 22:241-243.

Middleton, F.M. and A.A. Rosen, 1956. Organic Contaminants Affecting the Quality of Water, Public Health Reports, $71(11): 1125-1133$.

Moore, G.E., R. Boes and L. Weaver, 1980. An Early Warning Organics Detection System for the Ohio River, J. AWWA, $72(1): 21-26$.

Morris, J.C. and G. McKay, 1975. Formation of Halogenated Organics by Chlorination of Water Supplies, A Review, Technical Report (EPA-600/1-75-002) USEPA, Washington, D.C.

Morrow, C.M. and R.A. Minear, 1983. A Non Linear

Regression Model Linking Raw Water Characteristics to THM Concentrations in Drinking Water. American Chemical Society Conference, Seattle, washington.

Nelson, G.R., 1978. Modeling Residual Chlorine Levels: closed-Cycle Cooling System. Water Chlorination: Environmental Impact and Health Effects, Ed. R.L. Jolley. Ann Arbor Science Publishers, Ann Arbor, MI. F. 345 . 
Noack, M.F. and R.L. Doerr, 1978. Reactions of Chlorine, Chlorine Dioxide and Mixtures Thereof With Humic

Acid: An Interim Report, Water Chlorination

Environmental Impact and Health Effects, Vol. I. Ed. R.L. Jolley. Ann Arbor Science Publishers, Ann Arbor, MI •

Norwood, D.L., J.D. Johnson and R.F. Christman, 1980. Reactions of Chlorine With Selected Aromatic Models of Quatic Humic Material, Environ. Sci. Technol., $14: 187-189$.

Oliver, B.G. and J. Lawrence, 1979. Haloforms in Drinking Water: A Study of Precursors and Precursor Removal, J. AWWA, $71(3): 161-163$.

Qualls, R.G. and J.D. Johnson, 1983. Kinetics of the Short-Term Consumption of Chlorine by Fulvic Acids, Environ. Sci. Technol. 17:692-698.

Reding, R., W.B. Kollman, M.J. Weisner and H.J. Brass, 1979. Trihalomethanes in Drinking Water: Analysis by Liquid-Liquid Extraction and a Comparison to purge and Trap, Measurement of Organic Pollutants in Water and Wastewater, C.E. VanHall, Editor, American Society of Testing Materials, Philadelphia, PA.

Rice, R.G., C. Gomella and G.W. Miller, 1978. Rouen France Water Treatment Plant: Good Organics and Ammonia Removal: Civil Engineering (5):76-82.

Rook, J.J., 1977. Chlorination Reactions of Fulvic Acids in Natural Waters, Environ. Sci. Technol. 11:478-482.

Rook, J.J., 1974. Formation of Haloforms During Chlorination of Natural Waters, water Treatment and Examination 23/Part 2: 234-243.

Saguinsin, J.L.S., and J.C. Morris, 1979. The Chemistry of Aqueous Nitrogen Trichloride, Disinfection of Water and Wastewater. Ed. J.D. Johnson. Ann Arbor Science Publishers, Ann Arbor, MI.

Saunier, B.M. and R.E. Selleck, 1979. The Kinetics of Breakpoint Chlorination in Continuous Flow Systems. JAWWA 71(3):164-172.

Scheuch, L.E. and J.K. Edwaltz, 1981. Removing color and Chloroform Precursors From Low Turbidity Waters by Direct Filtration. JAWWA 73(9):497-502. 
Sloan, G., 1981. Alternative to Reducing TTHMs Found. Letter to the Editor, The Overflow. American Water Works Association, Denver, Co.

Smith, V.L., I. Cech, J.H. Brown and G.F. Bogdan, 1980. Temporal Variations in Trihalomethane Content of Drinking Water, Environ. Sci. Technol., 14:190-196.

Sorber, C.A., R.F. Willlams and B.E. Moore, 1982. Alternative Water Disinfection Schemes for Reduced Trihalomethane Formation. Technical Report (EPA-600/52-82-037) USEPA Cincinnati, OH.

Stevens, A.A., D.R. Seegar, J.DeMarco and L. Moore, 1979. Removal of Higher Molecular Weight Organic Compounds by the Granular Activated Carbon Adsorption Unit Process. Proceedings of Practical Applications of Adsorption Techniques in Drinking water. Reston, VA. Sponsored by USEPA, Cincinnati., OH.

Stevens, A.A., C.J. Slocum, D.R. Seegar and G.C. Robeck, 1976. Chlorination of Organics in Drinking Water. JAWWA 681(11):615-620.

Symons, J.M., A.A. Stevens, R.M. Clark, E.E. Geldreich, O.T. Love and J. DeMarco, 1981a. Removing Trihalomethanes from Drinking Water-An Overview of Treatment Techniques, Water Engineering and Management. USEPA, Cincinnati, OH.

Symons, J.M., A.A. Stevens, R.M. Clark, E.E. Geldreich, O.T. Love and J. DeMarco, 1981b. Treatment Techniques for Controllilng Trihalomethanes in Drinking Water, Technical Report (EPA-600/2-81-156), USEPA, Cincinnati, OH.

Thurrott, J.C., H. Zwart-Duryea, J.R. Sloane and D. Williamson, 1983. Trihalomethane Removal by Coagulation Techniques in A Softening Process, Technical Report (EPA-600/52-83-003). USEPA, Cincinnati, $\mathrm{OH}$.

Trussel, R.R., and M.D. Umphres, 1978. The Formation of Trihalomethanes. JAWWA 70(11):604-612.

Uden, P.C. and J.W. Miller, 1983. Chlorinated Acids and Chloral in Drinking Water. JAWWA 75(10):524-527.

Umphres, M.D., A.R. Trussell, S.H. Tate, and H.R. Trussell, 1983. Trihalomethanes in Drinking Water, Water Engineering and Management, 4:265-276. 
Urano, D.K., H. Wada and T. Takemasa, 1983. Empirical Rate Equation for Trihalomethane Formation with Chlorination of Humic Substances in Water, water Research, 17:1797-1802.

Wei, I.W. and J.C. Morris, 1974. Dynamics of Breakpoint Chlorination. Chemistry of Water Supply Treatment and Distribution. Ed., A.J. Rubin. Ann Arbor Science Publishers, Ann Arbor, MI.

Wong, G.T.F. and J.A. Davidson, 1977. The Rate of Chlorine in Sea Water. Water Research 11:971-978.

Wood, P.R. and J. DeMarco, 1979. Treatment of Groundwater with Granular Activated Carbon. JAWWA 71(11):674-682.

Wood, P.R. and J. DeMarco, 1980. Effectiveness of Various Adsorbents in Removing Organic Compounds From Water-Removing Purgeable Halogenated Organics, Activated Carbon Adsorption of Organics from the Agueous PHase. Eds., M.J. McGuire, I.H. Suffet. Ann Arbor Science Publishers, Ann Arbor, MI.

Zielke, R.L., H.B. Flora and S.K. Macey, 1978. Validation of a Kinetic Model to Predict Total Residual Chlorine in Fresh Water, Water Chlorination: Environmental Impacts and Health Effects. Ed., R.L. Jolley. Ann Arbor Science Publishers, Ann Arbor, Mi.

Zika, R.G., R.G. Petasne and W.J. Cooper, 1982. Sunlight Induced Photodecomposition of $\mathrm{HOCl} / \mathrm{OCl}-\mathrm{HOBr} / \mathrm{OBr}$ - and $\mathrm{NH}_{2} \mathrm{Cl}$ During Water Treatment, Proceeding of the AWWA Water Technical Conference, Miami Beach, FL, May 16-21, 1982 . 